\title{
Implications of COVID-19 in pediatric rheumatology
}

\author{
Ezgi Deniz Batu ${ }^{1}$ (D) Seza Özen ${ }^{1}(\mathbb{C}$
}

Received: 2 May 2020 / Accepted: 27 May 2020 / Published online: 4 June 2020

(c) Springer-Verlag GmbH Germany, part of Springer Nature 2020

\begin{abstract}
COVID-19 (coronavirus disease 2019) pandemic caused by SARS-CoV-2, is a global public health issue threatening millions of lives worldwide. Although the infection is mild in most of the affected individuals, it may cause severe clinical manifestations such as acute respiratory distress syndrome or cytokine storm leading to death. Children are affected less, and most experience a milder disease. As rheumatologists, we deal with the uncontrolled response of the immune system, and most of the drugs we use are either immune modulators or immunosuppressants. Thus, the rheumatologists participate in the multidisciplinary management of COVID-19 patients. On the other hand, our patients with rheumatic diseases constitute a vulnerable group in this pandemic. In this review, a systematic literature search was conducted utilizing MEDLINE/ PubMed and Scopus databases, and 231 COVID-19 patients with rheumatic diseases have been identified. Only one of these patients was a child. Among these, 9 (3.9\%) died due to COVID-19. In light of the current data, the aspects of COVID-19 resembling rheumatic diseases, the possible reasons for why children are affected less severely, the hypothetic role of available vaccines in preventing COVID-19, the unique position of patients with rheumatic diseases in this pandemic, and the use of anti-rheumatic drugs in COVID-19 treatment are discussed.
\end{abstract}

Keywords COVID-19 $\cdot$ COVID-19 virus $\cdot$ SARS-CoV-2 $\cdot$ Rheumatic disease $\cdot$ Systemic lupus erythematosus $\cdot$ Familial Mediterranean fever

\section{Introduction}

In late December 2019, a severe coronavirus outbreak emerged in China. It was caused by a novel virus, SARS$\mathrm{CoV}-2$ (severe acute respiratory syndrome coronavirus 2 ) from coronoviridae family $[1,2]$. The infection quickly spread over the world. The World Health Organization (WHO) officially named this infection as COVID-19 (coronavirus disease 2019) on February 11th, 2020, and declared COVID-19 a pandemic on March 11th, 2020. There are $4,088,848$ confirmed cases and 283,153 deaths ascribed to

\section{Electronic supplementary material The online version of this} article (https://doi.org/10.1007/s00296-020-04612-6) contains supplementary material, which is available to authorized users.

Ezgi Deniz Batu

ezgidenizbatu@yahoo.com

Seza Özen

sezaozen@gmail.com

1 Division of Rheumatology, Department of Pediatrics, Hacettepe University Faculty of Medicine, Ankara 06100, Turkey
COVID-19 worldwide as of May 12th, 2020 (source: WHO Situation Report 113). It has a mortality rate around 7\%; however, this could be an overestimation since not everyone is being tested for COVID-19. The main route of transmission is person-to-person via respiratory droplets [3, 4]. Primary prevention strategies such as quarantine, social distancing, and hand hygiene are the main methods to prevent the infection since there has been no vaccine or specific antiviral treatment yet.

SARS-CoV-2 has considerable genetic resemblance (around $80 \%$ ) with SARS-CoV virus, which was the causative organism of the 2002 SARS (severe acute respiratory syndrome) epidemic [5, 6]. SARS-CoV-2 has spike proteins on its surface, and using these proteins, it binds to target human cells. The receptor for SARS-CoV-2 is angiotensinconverting enzyme 2 (ACE2) mainly expressed on epithelial cells, renal proximal tubular cells, enterocytes, and endothelial cells [5, 7]. After attachment to ACE2, the virus is endocytosed into the cell and interacts with tall-like receptors (TLRs) inside the endosome. This interaction promotes a type I interferon (IFN) response and increases the expression 
of other proinflammatory cytokines through nuclear factor кB (NF-кB) [8, 9].

There are two main reactions of the immune system to this virus: an initial innate immune response through type I IFNs (described above) and a secondary adaptive immune response, which may lead to cytokine storm. The initial IFN response aims to contain and clear the virus effectively, and an early peak seems crucial for this effective control [10]. The resolution of IFN activity generated during an innate immune response is required for recovery [11]. After the initial IFN response, macrophages are activated through their IFN- $\alpha / \beta$ receptors and produce chemoattractants and proinflammatory cytokines [12]. Another reaction to the virus is the presentation of spike protein antigens to $\mathrm{T}$ cells by antigen-presenting cells, which results in the activation of $\mathrm{B}$ cells and the production of anti-spike immunoglobulins. When these immunoglobulins bind to spike proteins of the viruses, coated viruses could be internalized into macrophages through $\mathrm{Fc}$ receptors [13]. These macrophages release proinflammatory cytokines, which may contribute to the cytokine storm in the adaptive phase [13, 14]. The cellular/tissue damage in COVID-19 probably occurs in two ways: (1) direct damage by the virus through viral replication and (2) the harmful effects of the exaggerated immune response resulting in a cytokine storm, which means the uncontrolled and excessive release of proinflammatory cytokines [15]. Mice and non-human primate studies showed that a disproportionate immune response rather than the virus titer was related to death in SARS-CoV infection $[16,17]$. The infection is mild in most of the affected individuals while it could cause a severe clinical situation, mainly characterized by acute respiratory distress syndrome (ARDS) and cytokine storm that can lead to mortality [18]. Cytokine storm is the result of uncontrolled immune activation which leads to hyperinflammation and multi-organ disease [19]. Although everyone is susceptible to being infected by this novel virus, COVID-19 affects a specific group of individuals with more severe disease. The main risk groups are elderly patients, smokers, and individuals with chronic diseases such as diabetes mellitus or hypertension [20-22].

As the pandemic ensues, we observe that children are affected less and most experience a mild form of the disease in case of infection $[4,23]$. In the cohort study, including 72,314 COVID-19 patients, Wu et al. reported that only $2 \%$ of the cases were below 19 years of age [24]. We assume that the immunosuppressant patients constituted a primary risk group for COVID-19. However, the current data have not conferred immunosuppression as a specific risk factor for severe or fatal disease consistent with the epidemiologic data from the previous coronavirus epidemics, namely SARS and MERS (Middle East respiratory syndrome) [25].

The drugs that are currently being used and tested in COVID-19 treatment are mostly the ones used by patients with rheumatic diseases. Thus, the rheumatologists participate in the multidisciplinary management of COVID-19 patients, as well. On the other hand, immunosuppressants put patients with rheumatic diseases in a vulnerable group in this pandemic. Thus, making effective and accurate decisions about management strategies regarding these patients is critical, and these should be based on the currently available scientific evidence as much as possible.

This review aims to provide an overview of COVID-19 pandemic from pediatric rheumatologist's perspective. The aspects of COVID-19 resembling rheumatic diseases, the possible reasons for why children are affected less severely, the hypothetic role of other available vaccines in preventing COVID-19, the unique position of patients with rheumatic diseases in this pandemic, the COVID-19 patients with rheumatic diseases in the literature, and COVID-19 treatment with the drugs used for rheumatic diseases are discussed. Also, a systematic literature search was conducted to identify COVID-19 patients with rheumatic diseases.

\section{Search strategy}

The Scopus and MEDLINE/PubMed databases were searched (from November 1st, 2019 to May 11th, 2020) by entering the following keywords; "coronavirus disease 2019", "COVID-19", "SARS-CoV-2", "rheumatology", and "rheumatic disease" according to the published guidance on narrative reviews [26]. The complete list of the search terms used for determining articles, including COVID-19 patients with rheumatic diseases, has been provided in the Supplementary Table 1. Case reports, original research articles, editorials, and review articles with a focus on COVID-19 were analyzed. The following parameters were noted from the studies including COVID-19 patients with an underlying rheumatic disease: age, sex, underlying rheumatic disease, age at diagnosis of the rheumatic disease, features associated with rheumatic disease, other comorbidities, the previous and current treatment of rheumatic disease, COVID19-related symptoms, the method for COVID-19 diagnosis, COVID-19 treatment and outcome, and features regarding cessation and re-initiation of immunosuppressive therapies. The search was restricted to English articles.

\section{COVID-19 patients with rheumatic diseases in the literature}

Seventeen articles describing 231 COVID-19 patients with rheumatic diseases were found during the literature search (Fig. 1) [27-43]. Among these patients, there was only one pediatric patient who was a 6-month-old infant with Kawasaki disease and COVID-19 [31]. The characteristics of 


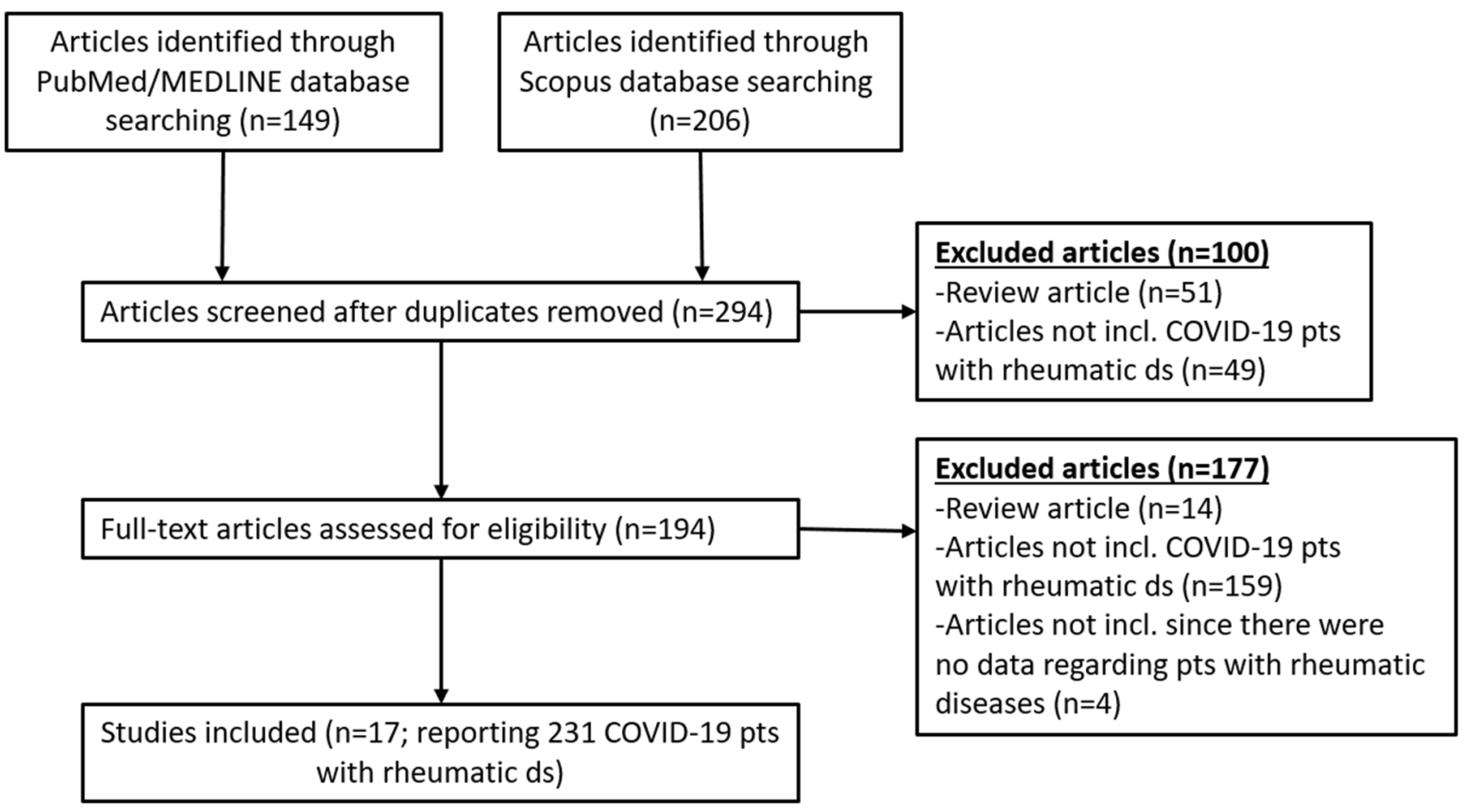

Fig. 1 The schematic overview of the studies on COVID-19 (coronavirus disease 2019) in patients with rheumatic diseases included in the literature research (pts, patients)

the patients are presented in Table $1.77 .5 \%$ of the patients were female $(n=179)$. The most common underlying rheumatic diseases were systemic lupus erythematosus (SLE) $(n=117)$ and rheumatoid arthritis (RA) $(n=45)$. Nine out of 231 (3.9\%) patients died. Of note, Konig et al. did not report outcomes with regard to mortality in their COVID19 cohort, including 80 SLE patients [41].

In addition to these articles presented in the table, four articles reported COVID-19 patients with rheumatic diseases [44-47]. These articles were not included since there were no details about these reported patients. Garg et al. presented age-stratified COVID-19-associated hospitalization rates of U.S. patients [44]. And in their report, there were three (out of 180) patients who were mentioned to have "rheumatic/autoimmune disease". One of these patients was in the age range of 18-49 years, while two were $\geq 65$ years of age. Xu et al. mentioned that there were gout patients in their COVID-19 cohort, including 187 patients [47]. In their patient experience survey study, Sirotich et al. reported that 465 patients with rheumatic diseases had a diagnosis of COVID-19 based on symptoms or physician diagnosis with positive laboratory tests [46]. However, no further details were provided about these patients, including their underlying rheumatic diseases. In the cohort of 1317 SARS-CoV-2 positive patients, Gendelman et al. reported that three were on chronic hydroxychloroquine (HCQ) and seven were on chronic colchicine treatment [45]. But they did not mention the underlying diseases in these patients.

\section{Why are children less affected?}

Currently, the exact reason why children experience a milder disease remains unknown. Several factors could contribute to this situation; however, the specific effects of these factors with regard to COVID-19 have not been studied yet:

1. Children travel less than adults which may be protective [48].

2. Smoking is not an issue in childhood, and the respiratory tracts of children have been exposed to air pollution for a shorter time compared to adults [48].

3. Common comorbidities of adulthood, like type 2 diabetes mellitus or hypertension, are not so frequent among children [9].

4. The upper respiratory tracts of children are usually colonized with a variety of microorganisms which may compete with SARS-CoV-2 [49-51].

5. In children, the innate immune response is more robust while the adaptive immune system is less educated and immature compared to adults $[9,52]$. This may result in a sufficient clearance of the virus and a lack of an exaggerated adaptive response. 


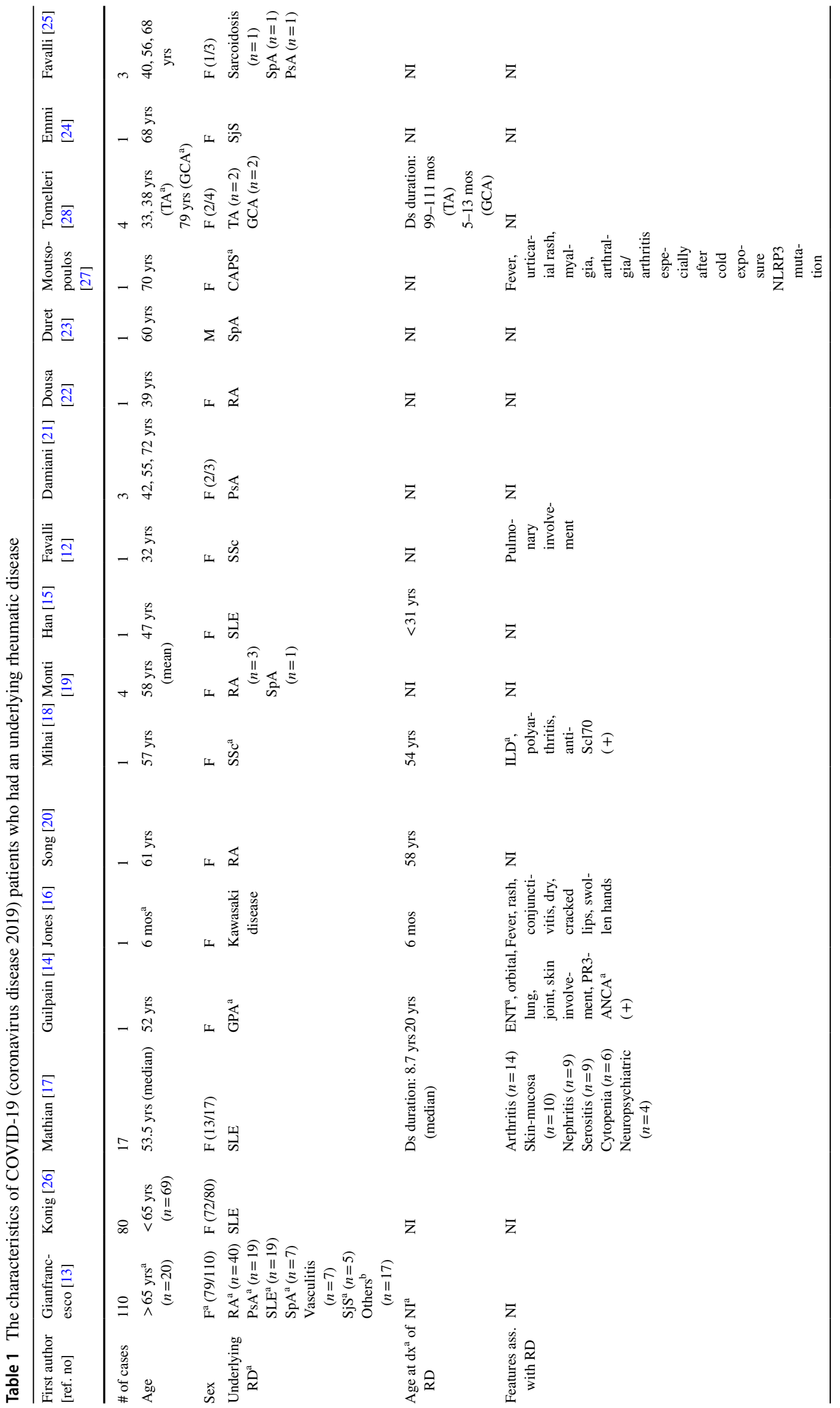




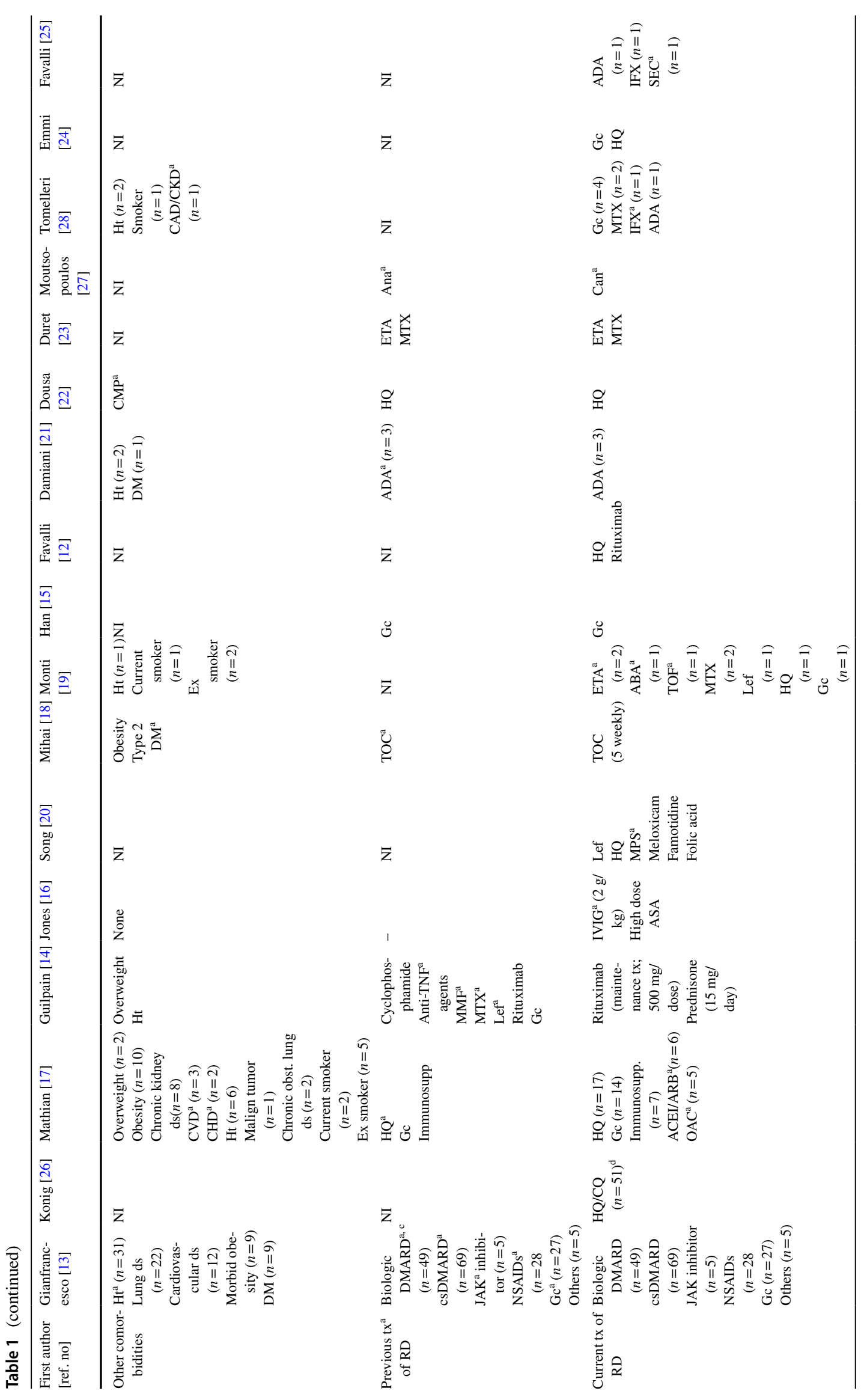




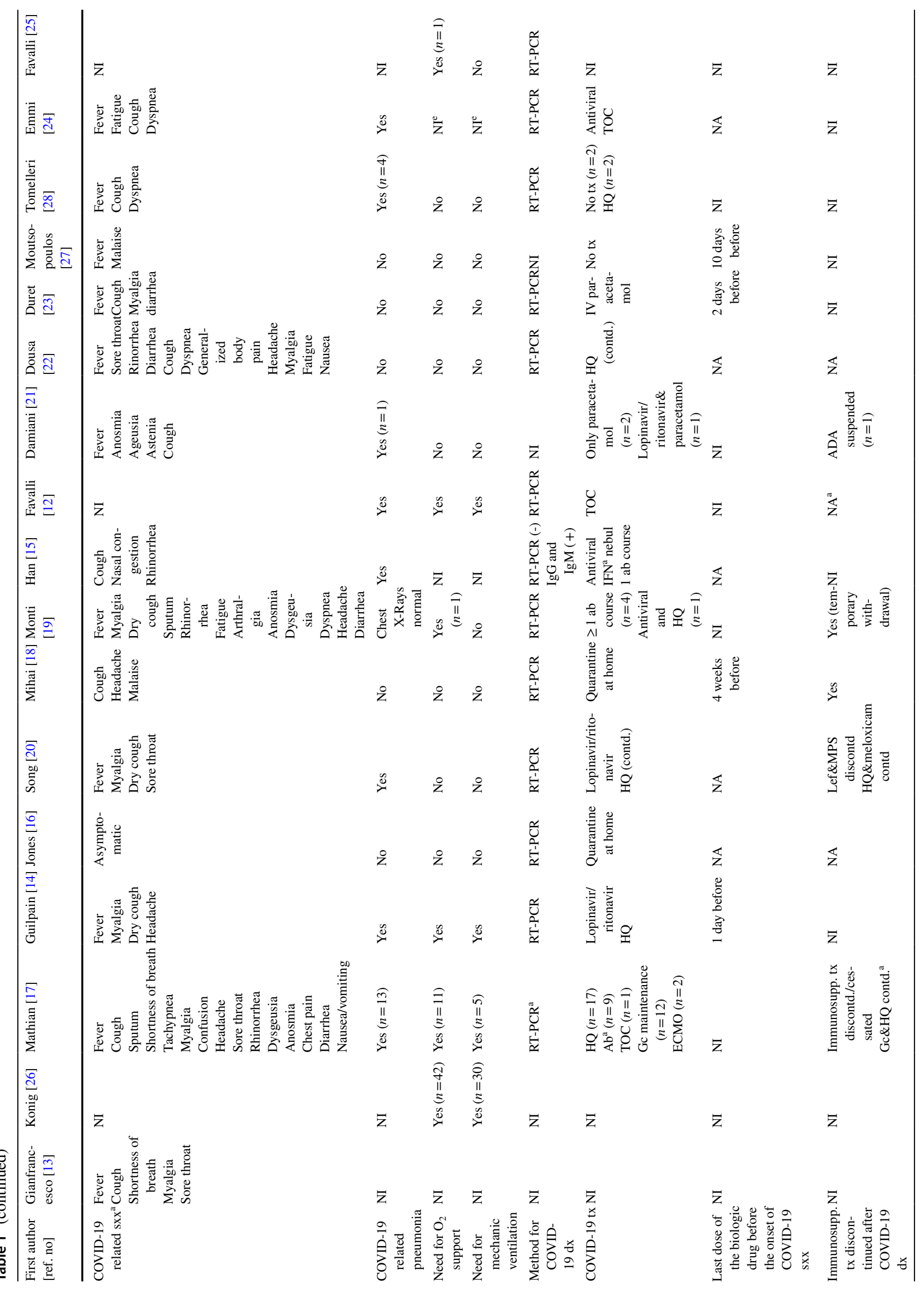




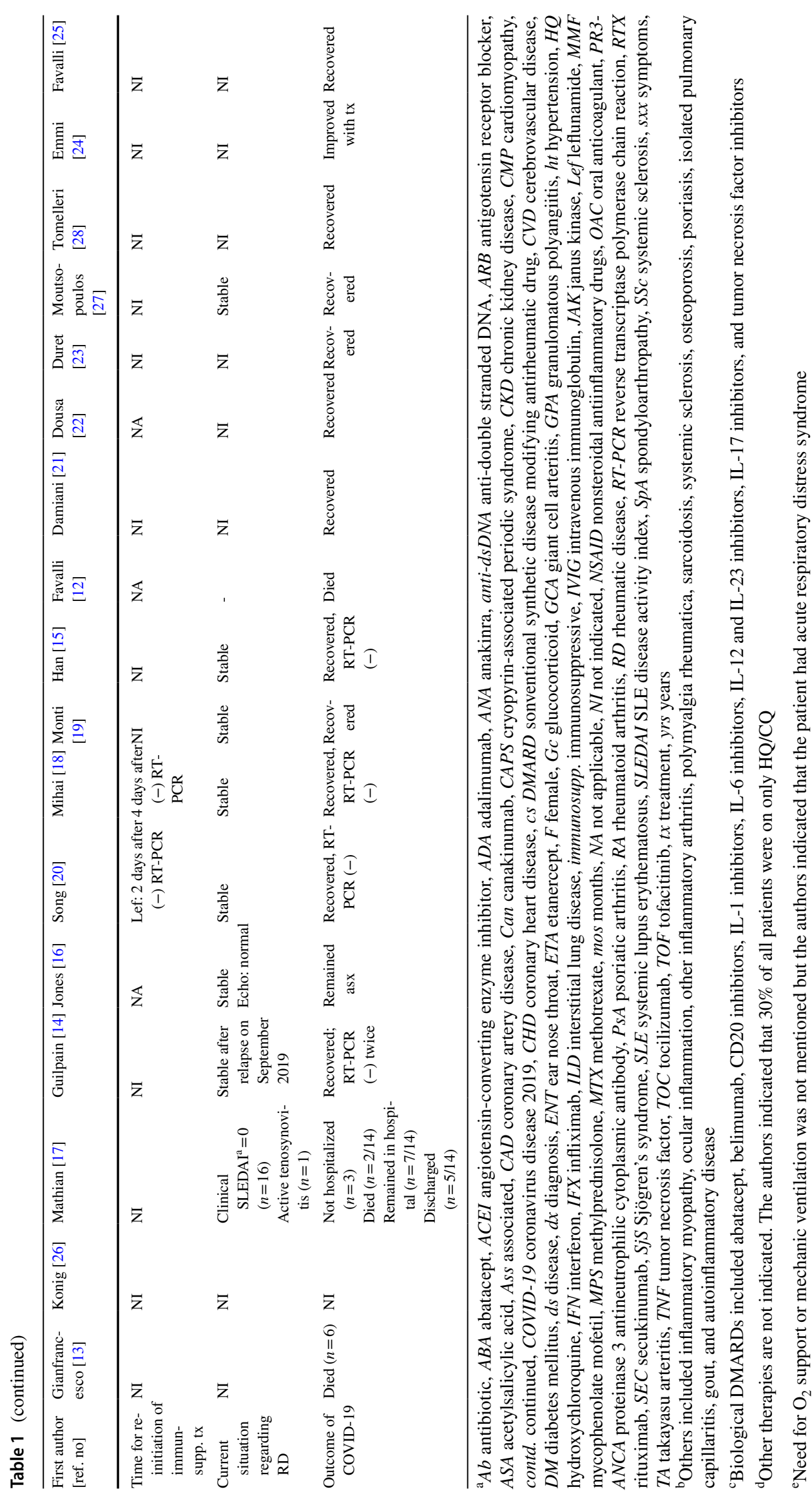


6. ACE2 expression patterns in children could be different than adults [53].

7. Last, some childhood vaccines may provide a protective effect against COVID-19 (discussed in detail below).

All of these factors could have a combined overall effect. However, we should keep in mind that children are not immune to COVID-19, and although rarely, the disease could be severe and complicated in children, as well [54]. And although the pandemic itself seems to affect children less severely, it endangers the mass vaccination programs of WHO against polio and measles [55]. This could result in epidemics of preventable infectious diseases, especially among children.

Another point that deserves mention here is neonates of COVID-19-positive mothers. Although anecdotal reports exist, there is no direct evidence about the vertical transmission of SARS-CoV-2 from mother to child [56]. Chen et al. detected no virus in amniotic fluid, umbilical cord blood, and breast milk samples from mothers with COVID-19 and pharynx swabs of neonates born to mothers with COVID19 [57].

Analyzing differences between different risk groups may provide critical clues about the disease pathogenesis. And, we may develop new strategies to fight against this novel foe.

\section{Do existing childhood vaccines protect against COVID-19?}

COVID-19 seems to affect different countries with varying severity. Several epidemiological and observational studies are performed, and the results show that differences in childhood vaccination policies may partially describe the difference in COVID-19 severity. However, nearly all of these articles are non-peer reviewed, and the results were derived from indirect analyzes of epidemiologic data. Thus, these studies are vulnerable to selection bias, and uncontrolled confounding factors might have significantly deviated the results. Some of these confounding factors are population age, ethnicity, testing rates for COVID-19 infection, the stage of the pandemic in each country, income levels, and major policy decisions (such as quarantine and providing self-protecting equipment like masks). Another limiting factor is that it is not possible to dissect the effect of one specific vaccine such as BCG (Bacillus Calmette-Guerin) with these kinds of studies since the associations may also be caused by another vaccine mediating the protective effect. Thus, the results of these observational and epidemiologic studies should be evaluated with caution considering all the mentioned points.

These studies mainly put forward two vaccines as candidates for reducing the damage caused by COVID-19: BCG and MMR (measles, mumps, rubella). It is noteworthy that the below discussed protective effects of childhood vaccines against COVID-19 are currently hypothetical, and no scientific proof has been published yet.

\section{BCG vaccine}

Bacillus Calmette-Guerin (BCG) is a live attenuated vaccine. It is derived from an isolate of Mycobacterium bovis and used as a vaccine for tuberculosis [58]. The epidemiologic analyzes showed that the incidence of COVID-19 and the death rate were significantly lower in countries with BCG vaccination programs compared to those without such a program [59]. It is not possible to draw reliable conclusions as of yet. However, previous studies, including randomized controlled trials, have suggested a "nonspecific protection against infections" induced by the BCG vaccine [60]. Since Mycobacterium is a bacterium while SARS$\mathrm{CoV}-2$ is a virus, it is unlikely that a protective effect comes from cross-protection based on similar molecular structures. Previous studies have shown two possible mechanisms that explain the nonspecific protection provided by the BCG vaccine [61]: heterologous immunity and trained immunity. Heterologous immunity means that CD4 and CD8 memory cells (produced by the BCG vaccine in this situation) could be activated in an antigen-independent manner [62-65]. This activation could be caused by cytokine stimulation by a secondary infection. It is known that the BCG vaccine induces histone modifications and epigenetic changes in human monocytes at the promoter sites of genes encoding for proinflammatory cytokines such as interleukin 6 (IL-6) and TNF- $\alpha$ (tumor necrosis factor) [66]. This causes a more active innate immune response after re-stimulation (trained immunity) [58, 61, 66], which may contribute to the effective clearance of the virus in case of COVID-19. Arts et al. have recently shown that $\mathrm{BCG}$ vaccination reduced the level of viremia after yellow fever vaccination, and this effect was correlated with the induction of cytokine response [61]. Another possible pathway may be through the activation of the IFN-gamma pathway. Two studies (NCT04328441, NCT04327206) are underway to test the nonspecific protective effect of BCG vaccine in COVID-19.

\section{Measles, Mumps and Rubella (MMR) vaccine}

Indirect epidemiologic analyses also suggest a protective role for the MMR vaccine against COVID-19 [67]. Bianchi et al. demonstrated that a considerable proportion of individuals did not show a protective immunoglobulin $\mathrm{G}(\mathrm{IgG})$ titer against measles in the 10 years after vaccination [68]. Shanker et al. hypothesized that age-related decline in immunogenicity of the measles vaccine could be an explanation for COVID-19 being mainly an adult 
disease if the measles vaccine provides cross-resistance to COVID-19 [69]. Franklin et al. demonstrated that IgG titers against rubella increased in SARS-CoV-2 infection in some cases, which might suggest a structural homology between rubella and SARS-CoV-2 [67]. They reported that there was $29 \%$ amino acid sequence homology existing between macro-domains of SARS-CoV-2 and rubella virus and $20 \%$ homology between fusion protein of measles virus and spike protein of SARS-CoV-2. This report is the only evidence supporting these data; however, this is a not-peer reviewed article, and it remains unknown whether this resemblance is enough to cause a cross-reactive immune defense.

It will take time for researchers to develop an effective vaccine against COVID-19. Thus, it is wise to analyze the cross-resistance from other vaccines that are already being used. However, these studies should be designed carefully to control confounding factors. Considering all available data, it is too early to conclude on a protective effect from any vaccine at the moment. Another point is that it is not possible to predict how fast the immune system will develop a response that will protect against COVID-19 (if this exists) after another vaccine such as BCG or MMR vaccines. At the moment, childhood vaccinations should be applied according to the routine vaccination schedules of each country. The recommendations about new vaccination plans could arise with accumulating evidence on cross-protectiveness of other vaccines for COVID-19.

\section{The features of COVID-19 that mimic rheumatic diseases}

The main characteristics of COVID-19, such as leukopenia, thrombocytopenia, myocarditis, and interstitial pneumonia, could also be observed in rheumatic diseases such as SLE and systemic sclerosis $[18,70,71]$. However, the clinically significant features are mainly from the inflammatory characteristics that mimic our diseases in both clinical features and pathogenesis. Having common pathways in the pathogenesis highlights some of the drugs that rheumatologists use as candidates for COVID-19 treatment.

Pediatric rheumatologists are very familiar with this entity since a significant portion of some common rheumatic diseases such as systemic juvenile idiopathic arthritis (JIA), SLE, and Kawasaki disease present this complication [72]. This secondary hemophagocytosis is called macrophage activation syndrome (MAS) in pediatric rheumatology practice. Thus, the experience of rheumatologists was important when we realized that the severe end of the COVID-19 clinical spectrum was a multisystem hyperinflammatory syndrome progressing to a cytokine storm with shock. This situation resembles secondary hemophagocytic lymphohistiocytosis (HLH) or MAS. Having said that, we should be aware that COVID-19-associated cytokine storm is not identical to MAS. It shares certain common features such as high ferritin, C-reactive protein (CRP), lactate dehydrogenase (LDH), low platelet, and lymphocyte counts [73]. But they also differ in some aspects. For instance, a decrease in the erythrocyte sedimentation rate (ESR) is commonly observed in MAS [74]. However, this does not seem to be a mandatory feature of COVID-19-associated cytokine storm [73, 75].

Moreover, Zhang et al. reported that patients with severe COVID-19 had persistently very high ESR [15]. Other interesting data come from autopsy findings of SARS-CoVinfected patients, demonstrating that secondary lymphoid tissues were destroyed [76]. This may explain the absence of splenomegaly as a significant feature of COVID-19-associated cytokine storm, although it is included as a criterion for diagnosing HLH [77]. There are scarce autopsy data regarding COVID-19. In one report of autopsy findings in two patients, Barton et al. reported that there was splenomegaly in one patient while they detected remote splenectomy in the other [78]. Menter et al. shared the autopsy findings of 21 COVID-19 patients, and they mentioned that they did not observe extensive depletion of lymphoid cells [79]. Increasing reports about the laboratory values and histopathological features of critically ill COVID-19 patients will provide more clues about the similarities and differences between COVID-19-associated cytokine storm and secondary HLH/ MAS. However, we believe that the experience of pediatric rheumatologists contributed to the management of these severe COVID-19 patients: anti-IL-1 and anti-IL-6 strategies have been employed in the cytokine storm of COVID-19 patients in most intensive care units [19].

Another similar feature to rheumatic diseases is immune complex vasculitis, which could be observed secondary to occlusion of blood vessels with immune complexes, including spike proteins and anti-spike immunoglobulins $[9,15]$. This may represent yet another form of immune complex vasculitis, such as the Hepatitis B-related polyarteritis nodosa (PAN) with immune complexes containing the HBsAg.

Skin lesions are increasingly reported features of COVID19 , and some of these are very similar to the findings of rheumatic diseases. Bouaziz et al. reported violaceous macules, livedoid rash, purpura (necrotic and non-necrotic), which are similar to skin manifestations of systemic vasculitis such as severe IgA vasculitis (Henoch-Schönlein purpura) and PAN [80]. They also mentioned chill blainlike lesions in their patients similar to the ones observed in interferonopathies like Aicardi-Goutieres syndrome and SAVI (STING-associated vasculitis with onset in infancy) [81]. Interestingly, chill-blain-like lesions were also found in children and adolescents who were otherwise asymptomatic with regard to COVID-19 [82]. This may well be 
because of the high IFN levels induced by the virus. On the other hand, one wonders whether background levels of high IFN would protect against COVID-19 in the children with autoinflammatory interferonopathies such as SAVI or Aicardi Goutières syndrome. Acro-ischemia was reported in COVID-19 patients, as well [83, 84]. This feature is also observed in severe vasculopathies such as deficiency of adenosine deaminase $2[85,86]$. These vascular lesions could be due to immune complex vasculitis or disseminated intravascular coagulation. Positive antiphospholipid antibodies may also contribute to the pathogenesis as recently reported [87]. We need more histopathologic data to understand the exact pathogenesis of these features.

Another surprising feature of COVID-19 was the development of a Kawasaki-like disease in children. Very recently, Riphagen et al. have reported hyperinflammatory shock in eight children with similar features to atypical Kawasaki disease, Kawasaki disease shock syndrome, or toxic shock syndrome [88]. Seven of these patients required mechanical ventilation for cardiovascular stabilization, although no significant respiratory involvement was observed. The initial tests for COVID-19 were negative in all. One of these children died after 6 days, and SARS-CoV-2 was detected postmortem. Another child was tested positive for SARS-CoV-2 after discharge. And, the authors mentioned that positive antibodies were detected afterward in seven children. The coronary arteries were severely dilated in one. C-reactive protein, procalcitonin, ferritin, triglycerides, and D-dimers were elevated in all. Of note, the ferritin level was highest in the child who died $(4220 \mathrm{Mg} / \mathrm{L}$ while the range was $277-1023 \mathrm{Mg} / \mathrm{L}$ in the rest of the series). The laboratory features observed in this clinical situation are very similar to those seen in Kawasaki disease shock syndrome. Li et al. previously demonstrated higher levels of CRP, procalcitonin, triglycerides, and D-dimers in patients with Kawasaki disease shock syndrome compared to patients with only Kawasaki disease [89].

Finally, COVID-19 has been reported to present with large vessel stroke in young patients [90].

\section{Considerations regarding patients with different rheumatic diseases: unanswered scientific questions}

There are still no data about the infection rate and course of COVID-19 in patients with rheumatic diseases, as mentioned above. Although the rheumatology practice mainly focuses on the immunosuppression caused by the disease itself or treatment of the disease, a variety of immune dysregulation besides immune suppression exists in different rheumatic diseases.
One group is autoinflammatory recurrent fever syndromes such as familial Mediterranean fever (FMF) or cryopyrinassociated periodic syndrome (CAPS). As we know, pyrin and NLRP3 inflammasomes are overactivated in FMF and CAPS, respectively [91, 92]. MEFV mutations (associated with FMF) were thought to provide an advantage against some infections such as tuberculosis or plague in the Mediterranean basin in the past [93]. The findings of the NIH (National Institute of Health) group suggested the idea that individuals carrying an $M E F V$ mutation might have a selective advantage against the plague [94]. What will be the effect in COVID-19? Will these patients eliminate SARSCoV-2 more efficiently? Or will the overactive inflammasome contribute further to the exaggerated immune response that complicate the disease? We do not know the answers at the moment.

CAPS also raises interesting questions. Activation of the NLRP3 inflammasome by SARS-CoV was observed previously $[95,96]$. Another microorganism that activates NLRP3 is Streptococcus pneumonia [97]. Previously, Walker et al. observed that pneumococcal vaccines could trigger a severe local and systemic inflammatory reaction in CAPS patients [98]. They hypothesized that further trigger by pneumococcal polysaccharides to an already over-activated NLRP3 inflammasome might have caused these reactions. This raised concern about the use of these vaccines in CAPS patients. Could the same concern be valid in case of COVID19? Since CAPS is a rare disease, the current data do not let us answer this question either. Another confounding factor is that FMF and CAPS patients are mainly on colchicine and anti-IL-1 therapies, which are currently being tested in COVID-19 treatment. To date, there is only one report of COVID-19 in a patient with CAPS (who was on anti-IL-1 treatment) who experienced a mild disease course and recovered in a couple of days without any treatment [42].

Previous data suggest that mutations in the main causative genes of primary HLH (such as gene encoding for perforin) were also associated with secondary HLH/MAS [99]. There are also other mutations in other genes such as $N L R C 4$ associated with rare monogenic autoinflammatory diseases causing a tendency to recurrent MAS. NLRC4related disease is characterized by early-onset recurrent fever, enterocolitis, and repeated episodes of MAS [100]. Patients carrying variants of these genes may also be more prone to cytokine storm associated with COVID-19. Future data about the course of COVID-19 in the setting of rare monogenic autoinflammatory diseases will provide further insights about the disease pathogenesis.

SLE is the prototype of the autoimmune diseases. And, the main risk factor seems like the immunosuppressive therapies we use in SLE treatment. However, Sawalha et al. reported that epigenetic dysregulation in SLE resulted in ACE2 overexpression, and this might cause a specific 
tendency to COVID-19 in this patient group [101]. Another debate in the literature focused on the hypothetical prophylactic effect of HCQ, which is used by a majority of SLE patients (discussed below).

Another issue is that most of the debate is on the patients we are already treating with an established diagnosis of a rheumatic disease. In a considerable amount of these patients, there is some degree of disease control, which means a balance between immune dysregulation (autoimmunity/autoinflammation) and immunosuppression/immune modulation (the therapies). The patients with rheumatic diseases who are not diagnosed/treated yet could form another specific vulnerable group for COVID-19.

Last, immunosuppression is a known risk factor for infections. Although it did not emerge as a risk factor during the previous coronavirus epidemics (SARS and MERS) and the situation remains unknown in the current COVID-19 pandemic [102], we still do not have enough evidence. It would be safe to consider these patients risky while taking precautions but not discontinuing immunosuppressive therapies since these are important for disease control. Moreover, active disease is a significant risk factor for an increased rate of infections [103, 104].

Data gathering through international rheumatology COVID-19 registries will provide answers to some questions in our minds. But it is essential not to make any early conclusions about resistance or tendency to COVID-19 regarding a specific rheumatic disease or treatment before solid scientific evidence is obtained.

\section{Treatment of COVID-19 and special considerations for patients with rheumatic diseases}

The hallmarks of COVID-19 treatment are currently antiviral drugs, drugs interfering with viral entry, and immunosuppressive drugs (mainly the ones targeting cytokines). Here, we will primarily focus on drugs that are used in rheumatology practice. Since an early strong immune response is required for the effective clearance of the virus while the following exaggerated adaptive immune response should be tuned, the timing and the duration of immunosuppressive therapies are very critical.

\section{Antiviral drugs}

Currently, there is no specific antiviral drug against SARSCoV-2. However, several broad-spectrum antivirals such as remdesivir and lopinavir/ritonavir have been proposed to be tested in COVID-19 treatment.
Remdesivir is a nucleotide analog and was effective against SARS-CoV, MERS-CoV, and bat CoV strains [105]. Grein et al. reported clinical improvement in $36(68 \%)$ out of 53 patients with severe COVID-19 who received at least one dose of remdesivir [106]. And, the mortality rate in this group was lower than the general mortality rate in severe COVID-19 (13\% versus $>50 \%$, respectively). However, in a recent, randomized, double-blind, placebo-controlled study (158 patients in remdesivir group versus 79 in the placebo group), Wang et al. reported that remdesivir was not associated with statistically significant clinical benefits although adequately tolerated by the patients [107]. There are ongoing clinical trials on remdesivir use in COVID-19 (e.g., NCT04280705, NCT04315948).

Lopinavir, a protease inhibitor, has also been tested in COVID-19 treatment. It is used combined with ritonavir, which inhibits CYP-3A-mediated metabolism of lopinavir. Previous reports showed that lopinavir/ritonavir had improved clinical outcomes in SARS and MERS patients [108]. In a recent, randomized-controlled trial in hospitalized adult COVID-19 patients (99 patients in lopinavir/ ritonavir group versus 100 in standard care group), Cao et al. reported that no benefit was associated with lopinavir/ ritonavir treatment beyond standard care [109]. Ongoing trials will provide further data regarding the efficacy and safety of lopinavir/ritonavir in COVID-19 treatment (e.g., ChiCTR2000029609; NCT04261907).

\section{NSAIDs (nonsteroidal anti-inflammatory drugs)}

NSAIDs (nonsteroidal anti-inflammatory drugs) are commonly used in rheumatology practice. Actually, they may be of benefit to the musculoskeletal symptoms of COVID-19 [110]. In pediatric rheumatology practice, NSAIDs are the primary therapeutic options, especially in the treatment of oligoarticular JIA. Ibuprofen has been reported to increase ACE2 expression [111]. And anecdotal reports exist on a severe disease course in patients using NSAIDs [112]. However, there is no current evidence for a specific causal association between NSAID use and a more severe disease course in COVID-19 [110, 113]. Previous studies have also suggested an association between NSAID use and higher rates of complications after respiratory tract infections [114, 115]. Currently it is not possible to draw solid, evidencebased conclusion on NSAID use over all.

\section{Glucocorticoids}

Glucocorticoids repress the transcription of proinflammatory genes [116]. They may be used in the management of sepsis and septic shock at small doses and short term [117]. Some studies show beneficial effects of glucocorticoids in the treatment of coronavirus (SARS and MERS) pneumonia 
[118-120]. On the other hand, some studies reported more adverse effects with the use of corticosteroids in coronavirus infection [121]. And most recently, Tsai et al. have demonstrated that an early corticosteroid treatment was associated with significantly increased hospital mortality in adult patients with influenza-associated ARDS [122]. Regarding COVID-19, Wu et al. demonstrated that methylprednisolone treatment appeared to decrease the risk of death among patients with acute respiratory distress syndrome [123]. In their retrospective cohort study including 46 COVID-19 patients, Wang et al. observed that early, lowdose, and short-term application of methylprednisolone was associated with better clinical outcomes while they did not show any significant difference with regard to mortality rate [124]. However, it is not possible to conclude on a positive effect since the data are scarce. At the moment, WHO recommends against routine glucocorticoid use in COVID19 treatment. Randomized controlled trials planned to analyze the effectiveness/safety of glucocorticoid therapy in COVID-19 patients (ChiCTR2000029386, NCT042273321, NCT042244591) will provide better evidence and may enlighten the role of glucocorticoids in COVID-19.

\section{Hydroxychloroquine}

Hydroxychloroquine (HCQ), an antimalarial agent, is the mainstay of treatment, especially in SLE [125]. Being a weak base, HCQ accumulates in acidic environments such as lysosomes and endosomes. And, by increasing the $\mathrm{pH}$ in endosomes, HCQ interferes with TLR-virus interaction [126]. It also interferes with glycosylation of ACE2 and maturation process of viral proteins $[15,126]$. As a result, it may prevent viral entry and subsequent stimulation of proinflammatory pathways. Considering these mechanisms, it appeared as a candidate for both prophylaxis and treatment in COVID-19. To assess its prophylactic use, Shah et al. systematically reviewed the literature and determined five studies (three in-vitro studies and two clinical opinions) [127]. Unfortunately, it is not possible to conclude on a prophylactic effect of HCQ based on these data. In the same lines, Gendelman et al. did not observe a protective effect of chronic HCQ use in their retrospective study, including 1317 COVID-19 patients [45]. Thus, there is no enough evidence supporting prophylactic use of HCQ, and further studies with a randomized controlled design are required.

In an open-label non-randomized clinical trial in a small patient group (20 patients and 16 controls), Gautret et al. showed that HCQ treatment was significantly associated with viral load reduction with more efficient results when azithromycin was added [128]. Studies are underway to obtain a better level of evidence (e.g., NCT04307693, NCT04323631).
Currently, HCQ is used in the treatment of COVID-19 in most countries and for prophylaxis in some. However, considering the lack of evidence supporting its prophylactic use and the risk of short supplies for patients who need this drug, prophylactic treatment should not be recommended at this stage. Monti et al. reported that 51 out of $80(64 \%)$ COVID-19 patients with SLE were taking HCQ/chloroquine (CQ) before infection with SARS-CoV-2 [34]. Moreover, the frequency of hospitalization did not differ with regard to $\mathrm{HCQ} / \mathrm{CQ}$ use [34].

HCQ is also associated with certain side-effects. Retinal toxicity is not a significant concern since it is mainly associated with its long-term use [129]. However, HCQ use has previously been associated with QT interval prolongation [130]. Besides, azithromycin, which has been used in combination with HCQ in COVID-19 treatment, is also a drug that can cause QT prolongation [131]. Thus, these drugs should be used with caution in the treatment of COVID19. Of note, Saleh et al. reported that they did not observe torsade de pointes or arrhythmogenic death in their large cohort of COVID-19 patients treated with CQ $(n=10)$ or HCQ $(n=191)$ [132]. But they mentioned that QTc interval was significantly longer in the combination group $(\mathrm{CQ} /$ $\mathrm{HCQ}+$ azithromycin) compared to the monotherapy group (CQ/HCQ only).

\section{JAK (janus kinase) inhibitors}

JAK (janus kinase) inhibitors are not used in pediatric rheumatology patients as extensively as they are used in adult rheumatology. But these drugs are currently used in the treatment of JIA and autoinflammatory interferonopathies $[133,134]$. JAK inhibitors have been suggested to interfere with viral entry by inhibiting AAK1, which is a key regulator of SARS-CoV-2 endocytosis (detailed above) [5]. They may also be beneficial by inhibiting the proinflammatory effects of IFNs in the exaggerated immune response phase. Baricitinib is a selective JAK1 and JAK2 inhibitor [135], and it may exert an antiviral effect at the doses used for treatment in RA [136], emerging as a potential treatment option in COVID-19. JAK inhibitors may be beneficial at the severe end of the spectrum, where IFN response contributes to the cytokine storm. Cameron et al. demonstrated a prominent IFN- $\alpha$ and IFN- $\gamma$ signaling in deceased SARS patients compared to a low IFN- $\alpha / \gamma$ signaling in patients discharged from hospital [11]. However, the window of opportunity at the early phase is very narrow and difficult to determine since the patient will be asymptomatic at this phase, and the viral entry will be shortly followed with a strong IFN response which is critical for viral clearance.

IFNs act through JAK/STAT pathway to increase the expression of IFN response genes, and type I IFNs are the primary defense against viral infections [137]. JAK 
inhibitors interfere with antiviral immune response, and increased risk of herpes zoster and simplex infections were previously reported with JAK inhibitor use [138]. Since the effective containment and clearance of the virus depends on an effective and abrupt type I IFN response, initiation of JAK inhibitors at the early phase of COVID-19 could interfere with the immune defense. Thus, the jury is out for the benefit of these drugs in COVID-19.

\section{Drugs targeting cytokines}

A cytokine storm similar to secondary HLH/MAS occurs in some patients with COVID-19. Huang et al. have demonstrated that serum levels of several proinflammatory cytokines, including IL-1, IL- 6 , and TNF- $\alpha$ increased in the hyperinflammatory phase of COVID-19 [2]. These data called for the use of drugs targeting cytokines (mainly anti-IL-6, anti-IL-1, and anti-TNF) as candidates for severe COVID-19 treatment.

Zhou et al. observed that IL-6 levels were higher in deceased COVID-19 patients than the survivors [21]. Other studies also reported elevation of IL-6 levels in patients with severe COVID-19 [123, 139]. Tocilizumab (IL-6 receptor monoclonal antibody) use was associated with significant clinical improvement in several observational studies [140-142]; however, there were no matched controls treated without tocilizumab in these studies. In their retrospective case-control study (20 patients treated with tocilizumab versus 25 patients treated without tocilizumab), Klopfenstein et al. reported that death and/or intensive care unit admissions were higher among patients treated without tocilizumab than those treated with tocilizumab $(72 \%$ versus $25 \%$, respectively) [143]. Sciascia et al. performed a pilot, prospective single-arm study $(n=100)$, and they reported an improvement in respiratory and laboratory parameters with tocilizumab treatment [144]. Moreover, there are a few case reports on the successful use of tocilizumab in the treatment of severe childhood COVID-19 [145, 146]. Based on these data, anti-IL-6 treatment is currently the most studied drug in the treatment of COVID-19-associated cytokine storm (NCT04322773, NCT04317092, NCT04320615, NCT04306705, NCT04324073, NCT04315298, ChiCTR2000029765, ChiCTR2000030796).

Anti-IL-1 drugs are also among the most promising therapies in cytokine storm associated with COVID-19. In a recent retrospective cohort study, Cavalli et al. evaluated anakinra treatment in COVID-19 [147]. They compared the outcome between 16 patients who were on only standard treatment (HCQ and lopinavir/ritonavir) in addition to mechanic ventilation and 29 patients who were taking highdose intravenous (IV) anakinra in addition to the standard treatment and mechanic ventilation. Both overall survival and mechanic ventilation-free survival were more frequent in the high-dose anakinra group than the standard treatment group ( $90 \%$ versus $56 \%$ and $72 \%$ versus $56 \%$, respectively). There are ongoing trials of anakinra in COVID-19 that will probably provide a higher level of evidence for the efficacy of this treatment (NCT04324021, NCT04330638). Anti-IL-1 treatment has indeed been suggested by some pediatric rheumatologists to be the first-line treatment [73].

There are also ongoing trials for anti-TNF use in COVID19 (ChiCTR2000030089, ChiCTR2000030580). A combination of different biologic agents may also be considered in selected, very severe cases.

\section{Other drugs}

In severe cases of secondary HLH/MAS, anti-IFN- $\gamma$ treatment is a critical therapeutic option. There is also an ongoing trial of omapalumab (anti-IFN- $\gamma$ monoclonal antibody) and anakinra in COVID-19 (NCT04324021).

There are also other registered trials planned to test the efficacy of leflunomid, ecluzimab, and ruxolitinib [148]. The readers are referred to the review by Lythgoe et al. summarizing all ongoing trials for the management of COVID-19 pandemic [148].

In addition to this trial, it is worth mentioning an openlabel, phase II trial for colchicine use in COVID-19 treatment [149].

\section{Convalescent plasma treatment}

Convalescent plasma treatment has emerged as a promising option for the control of severe COVID-19 in the absence of specific antivirals. It is a strategy of passive immunization based on utilizing the hyperimmune $\operatorname{IgG}$ antibodies produced by individuals after recovering from COVID-19 [150]. In several case series, clinical improvement and reduction in the viral load have been reported [151-155]. However, there were no matched controls in these studies. Thus, the ongoing clinical trials will probably provide a higher level of evidence and data about the efficacy and safety of convalescent plasma therapy in COVID-19. We should also be cautious considering the potential severe reactions associated with convalescent plasma use such as anaphylactic reactions or transfusion-related acute lung injury [150].

\section{Considerations for patients with rheumatic diseases regarding their treatment}

At the moment, all international rheumatology societies, including ACR (American College of Rheumatology), EULAR (European League Against Rheumatism), and PReS (Pediatric Rheumatology European Society) recommend continuation of immunosuppressive treatment 
in patients with rheumatic diseases. Previous studies on SLE and RA patients provided data on the increased rate of infections in cases of high disease activity [103, 104]. Thus, the primary aim should be an effective disease control in our patients with rheumatic diseases.

A considerable amount of rheumatology patients are on drugs that are currently being tested for prophylaxis or treatment of COVID-19. And it is difficult to predict the effects of being already on these treatments on infection rate and severity.

As discussed above, there is a concern for more severe disease in patients using NSAIDs. To be on the safe site, NSAIDs may not be proposed as a primary treatment of rheumatic diseases or may be discontinued if they are not the primary drugs for disease control during COVID-19 pandemic. And for pain control, acetaminophen could be selected over NSAIDs.

Since HCQ is an immunomodulatory rather than immunosuppressive drug, and it probably interferes with viral entry, it might have a protective effect for patients treated with HCQ. However, SLE patients should not be considered resistant to COVID-19. Recently, there are increasing reports of COVID-19 patients with SLE [28, 30, 32, 41]. Mathian et al. have reported the clinical picture of the course of COVID-19 in SLE patients treated with HCQ [32]. The authors concluded that HCQ does not seem to prevent COVID-19, at least its severe forms, in patients with SLE since most of the SLE patients in this study received long-term treatment with $\mathrm{HCQ}$, having blood concentrations of the drug within the therapeutic range. The findings of Konig et al. were in the same lines, as mentioned above [41].

The data about glucocorticoid use are also complex and challenging to interpret. As pediatric rheumatologists, we are always aiming to decrease glucocorticoid use and to keep the glucocorticoid dose as low as possible to control disease activity. Probably, following the same principle will be logical until we get more evidence.

Most of the other drugs such as JAK inhibitors, anti-IL-1, anti-IL-6, and anti-TNF agents are immunosuppressives, and these might interfere with the effective clearance of the virus at early phases of the disease. Thus, being on these drugs at the early phase of infection could be a disadvantage for rheumatology patients. On the other hand, these drugs might prevent the development of a cytokine storm, making a milder disease course possible. Currently, there is not enough data about COVID-19 disease course in patients with rheumatic diseases that are treated with biologic drugs (Table 1). In a survey study from Italy, Filocamo et al. reported that there was no confirmed COVID-19 case among 123 pediatric patients on biologic DMARDs for chronic rheumatic diseases [156]. Current guidelines recommend continuing all immunosuppressive therapies providing disease control, and proper patient education against the virus.

During active COVID-19, the immunosuppressive therapy was discontinued in most rheumatology patients [29, 32-35]. Another important topic is when to re-initiate these therapies. In the case reports Song et al. [35] and Mihai et al. [33], the immunosuppressive therapies were re-initiated 2-4 days after a negative test result for COVID-19. In their expert opinion article, Sarzi-Puttini et al. suggested that these drugs should be re-initiated only after two negative swabs [157].

Last but not least, how will our decisions be affected while initiating treatment for the patients that are newly diagnosed with a rheumatic disease during COVID-19 pandemic? If possible, it may be recommended to test for SARS-CoV-2 before initiating biologics as we do for tuberculosis. However, the exact response to this question remains unknown currently. This issue will also be a hot topic when the pandemic is over since we currently do not know about the possibility of latent disease in COVID-19.

Gupta et al. performed a survey among rheumatologists in India to assess the attitudes of physicians while initiating anti-rheumatic therapies during COVID-19 pandemic [158]. They observed that almost $60 \%$ of the respondents preferred an earlier taper of glucocorticoids during inactive disease. $66.5 \%$ of the respondents were more inclined to initiate HQ in patients with borderline indications. And, almost half reduced the usage of biologic drugs.

\section{Conclusion}

COVID-19 pandemic has a high mortality rate and a poorer outcome, particularly in elderly patients and individuals with comorbidities. There are very limited data about the infection rate and disease course in patients with rheumatic diseases and almost no data regarding pediatric rheumatology patients. We should continue the medicines that control the disease activity in pediatric rheumatology patients since uncontrolled disease and high disease activity place patients to a higher risk group with regard to infections. Having said that one needs to decide on treatment on an individual basis, considering personal risk factors. It is critical not to reach early conclusions about the prophylactic effects of the drugs we currently use in pediatric rheumatology practice. And although the disease mostly has a mild course in children, children are not immune to COVID-19, and different clinical manifestations such as Kawasaki-like disease are being related to SARS-CoV-2 infection. We should use the accumulating current scientific evidence and common sense while making decisions about the treatment of our patients and follow the primary prevention principles such as hand hygiene and social distancing. 
Author contributions EDB designed the structure of the article, performed the literature review, and wrote the first draft of the manuscript. SO contributed to the literature review, drafted and critically revised the text. Both authors approved the final version of the manuscript.

Funding No funding was received for this study.

\section{Compliance with ethical standards}

Conflict of interest The authors declare no conflict of interest.

Ethical approval No part of the review is copied or published elsewhere and both co-authors take full responsibility for the integrity of the study.

\section{References}

1. Chan JF, Yuan S, Kok KH, To KK, Chu H, Yang J, Xing F, Liu J, Yip CC, Poon RW, Tsoi HW, Lo SK, Chan KH, Poon VK, Chan WM, Ip JD, Cai JP, Cheng VC, Chen H, Hui CK, Yuen KY (2020) A familial cluster of pneumonia associated with the 2019 novel coronavirus indicating person-to-person transmission: a study of a family cluster. Lancet 395:514-523. https://doi.org/10.1016/S0140-6736(20)30154-9

2. Huang C, Wang Y, Li X, Ren L, Zhao J, Hu Y, Zhang L, Fan G, Xu J, Gu X, Cheng Z, Yu T, Xia J, Wei Y, Wu W, Xie X, Yin W, Li H, Liu M, Xiao Y, Gao H, Guo L, Xie J, Wang G, Jiang R, Gao Z, Jin Q, Wang J, Cao B (2020) Clinical features of patients infected with 2019 novel coronavirus in Wuhan, China. Lancet 395:497-506. https://doi.org/10.1016/S0140 $-6736(20) 30183-5$

3. Rothan HA, Byrareddy SN (2020) The epidemiology and pathogenesis of coronavirus disease (COVID-19) outbreak. J Autoimmun 109:102433. https://doi.org/10.1016/j.jaut.2020.102433

4. Licciardi F, Giani T, Baldini L, Favalli EG, Caporali R, Cimaz $\mathrm{R}$ (2020) COVID-19 and what pediatric rheumatologists should know: a review from a highly affected country. Pediatr Rheumatol Online J 18:35. https://doi.org/10.1186/s12969-020-00422-Z

5. Lu R, Zhao X, Li J, Niu P, Yang B, Wu H, Wang W, Song H, Huang B, Zhu N, Bi Y, Ma X, Zhan F, Wang L, Hu T, Zhou H, Hu Z, Zhou W, Zhao L, Chen J, Meng Y, Wang J, Lin Y, Yuan J, Xie Z, Ma J, Liu WJ, Wang D, Xu W, Holmes EC, Gao GF, Wu G, Chen W, Shi W, Tan W (2020) Genomic characterisation and epidemiology of 2019 novel coronavirus: implications for virus origins and receptor binding. Lancet 395:565-574. https://doi. org/10.1016/S0140-6736(20)30251-8

6. Zhou P, Yang XL, Wang XG, Hu B, Zhang L, Zhang W, Si HR, Zhu Y, Li B, Huang CL, Chen HD, Chen J, Luo Y, Guo H, Jiang RD, Liu MQ, Chen Y, Shen XR, Wang X, Zheng XS, Zhao K, Chen QJ, Deng F, Liu LL, Yan B, Zhan FX, Wang YY, Xiao GF, Shi ZL (2020) A pneumonia outbreak associated with a new coronavirus of probable bat origin. Nature 579:270-273. https ://doi.org/10.1038/s41586-020-2012-7

7. Chen J, Subbarao K (2007) The Immunobiology of SARS*. Annu Rev Immunol 25:443-472. https://doi.org/10.1146/annur ev.immunol.25.022106.141706

8. Du Toit A (2016) Viral infection: changing sides to get in. Nat Rev Microbiol 14:476-477. https://doi.org/10.1038/nrmic ro. 2016.98
9. Hedrich CM (2020) COVID-19-considerations for the paediatric rheumatologist. Clin Immunol 214:108420. https://doi. org/10.1016/j.clim.2020.108420

10. Channappanavar R, Fehr AR, Vijay R, Mack M, Zhao J, Meyerholz DK, Perlman S (2016) Dysregulated type I interferon and inflammatory monocyte-macrophage responses cause lethal pneumonia in SARS-CoV-infected mice. Cell Host Microbe 19:181-193. https://doi.org/10.1016/j.chom.2016.01.007

11. Cameron MJ, Ran L, Xu L, Danesh A, Bermejo-Martin JF, Cameron CM, Muller MP, Gold WL, Richardson SE, Poutanen SM, Willey BM, DeVries ME, Fang Y, Seneviratne C, Bosinger SE, Persad D, Wilkinson P, Greller LD, Somogyi R, Humar A, Keshavjee S, Louie M, Loeb MB, Brunton J, McGeer AJ, Canadian SRN, Kelvin DJ (2007) Interferon-mediated immunopathological events are associated with atypical innate and adaptive immune responses in patients with severe acute respiratory syndrome. J Virol 81:8692-8706. https://doi. org/10.1128/JVI.00527-07

12. Ye Q, Wang B, Mao J (2020) The pathogenesis and treatment of the 'Cytokine Storm' in COVID-19. J Infect. https://doi. org/10.1016/j.jinf.2020.03.037

13. Liu L, Wei Q, Lin Q, Fang J, Wang H, Kwok H, Tang H, Nishiura K, Peng J, Tan Z, Wu T, Cheung KW, Chan KH, Alvarez X, Qin C, Lackner A, Perlman S, Yuen KY, Chen Z (2019) Anti-spike IgG causes severe acute lung injury by skewing macrophage responses during acute SARS-CoV infection. JCI Insight. https ://doi.org/10.1172/jci.insight.123158

14. Fu Y, Cheng Y, Wu Y (2020) Understanding SARS-CoV-2-mediated inflammatory responses: from mechanisms to potential therapeutic tools. Virol Sin. https://doi.org/10.1007/s12250-02000207-4

15. Zhang W, Zhao Y, Zhang F, Wang Q, Li T, Liu Z, Wang J, Qin Y, Zhang X, Yan X, Zeng X, Zhang S (2020) The use of antiinflammatory drugs in the treatment of people with severe coronavirus disease 2019 (COVID-19): the perspectives of clinical immunologists from China. Clin Immunol 214:108393. https:// doi.org/10.1016/j.clim.2020.108393

16. Rockx B, Baas T, Zornetzer GA, Haagmans B, Sheahan T, Frieman M, Dyer MD, Teal TH, Proll S, van den Brand J, Baric R, Katze MG (2009) Early upregulation of acute respiratory distress syndrome-associated cytokines promotes lethal disease in an aged-mouse model of severe acute respiratory syndrome coronavirus infection. J Virol 83:7062-7074. https://doi.org/10.1128/ JVI.00127-09

17. Smits SL, de Lang A, van den Brand JM, Leijten LM, Eijkemans MJ, van Amerongen G, Kuiken T, Andeweg AC, Osterhaus AD, Haagmans BL (2010) Exacerbated innate host response to SARSCoV in aged non-human primates. PLoS Pathog 6:e1000756. https://doi.org/10.1371/journal.ppat.1000756

18. Misra DP, Agarwal V, Gasparyan AY, Zimba O (2020) Rheumatologists' perspective on coronavirus disease 19 (COVID-19) and potential therapeutic targets. Clin Rheumatol. https://doi. org/10.1007/s10067-020-05073-9

19. Henderson LA, Canna SW, Schulert GS, Volpi S, Lee PY, Kernan KF, Caricchio R, Mahmud S, Hazen MM, Halyabar O, Hoyt KJ, Han J, Grom AA, Gattorno M, Ravelli A, de Benedetti F, Behrens EM, Cron RQ, Nigrovic PA (2020) On the alert for cytokine storm: immunopathology in COVID-19. Arthritis Rheumatol. https://doi.org/10.1002/art.41285

20. Vardavas CI, Nikitara K (2020) COVID-19 and smoking: a systematic review of the evidence. Tob Induc Dis 18:20. https://doi. org/10.18332/tid/119324

21. Zhou F, Yu T, Du R, Fan G, Liu Y, Liu Z, Xiang J, Wang Y, Song B, Gu X, Guan L, Wei Y, Li H, Wu X, Xu J, Tu S, Zhang Y, Chen H, Cao B (2020) Clinical course and risk factors for mortality of adult inpatients with COVID-19 in Wuhan, China: 
a retrospective cohort study. Lancet 395:1054-1062. https://doi. org/10.1016/S0140-6736(20)30566-3

22. Haslak F, Yildiz M, Adrovic A, Barut K, Kasapcopur O (2020) Childhood rheumatic diseases and COVID-19 pandemic: an intriguing linkage and a New Horizon. Balkan Med J. https:// doi.org/10.4274/balkanmedj.galenos.2020.2020.4.43

23. Dong Y, Mo X, Hu Y, Qi X, Jiang F, Jiang Z, Tong S (2020) Epidemiology of COVID-19 among children in China. Pediatrics. https://doi.org/10.1542/peds.2020-0702

24. Wu Z, McGoogan JM (2020) Characteristics of and important lessons from the coronavirus disease 2019 (COVID-19) outbreak in China: summary of a report of 72314 cases from the Chinese center for disease control and prevention. JAMA. https://doi. org/10.1001/jama.2020.2648

25. D’Antiga L (2020) Coronaviruses and immunosuppressed patients: the facts during the third epidemic. Liver Transpl. https ://doi.org/10.1002/lt.25756

26. Gasparyan AY, Ayvazyan L, Blackmore H, Kitas GD (2011) Writing a narrative biomedical review: considerations for authors, peer reviewers, and editors. Rheumatol Int 31:14091417. https://doi.org/10.1007/s00296-011-1999-3

27. Favalli EG, Agape E, Caporali R (2020) Incidence and clinical course of COVID-19 in patients with connective tissue diseases: a descriptive observational analysis. J Rheumatol. https://doi. org/10.3899/jrheum.200507

28. Gianfrancesco MA, Hyrich KL, Gossec L, Strangfeld A, Carmona L, Mateus EF, Sufka P, Grainger R, Wallace Z, Bhana S, Sirotich E, Liew J, Hausmann JS, Costello W, Robinson P, Machado PM, Yazdany J, Committee C-GRAS (2020) Rheumatic disease and COVID-19: initial data from the COVID-19 global rheumatology alliance provider registries. Lancet Rheumatol. https://doi.org/10.1016/S2665-9913(20)30095-3

29. Guilpain P, Le Bihan C, Foulongne V, Taourel P, Pansu N, Maria ATJ, Jung B, Larcher R, Klouche K, Le Moing V (2020) Rituximab for granulomatosis with polyangiitis in the pandemic of covid-19: lessons from a case with severe pneumonia. Ann Rheum Dis. https://doi.org/10.1136/annrheumdis-2020-217549

30. Han Y, Jiang M, Xia D, He L, Lv X, Liao X, Meng J (2020) COVID-19 in a patient with long-term use of glucocorticoids: a study of a familial cluster. Clin Immunol 214:108413. https:// doi.org/10.1016/j.clim.2020.108413

31. Jones VG, Mills M, Suarez D, Hogan CA, Yeh D, Bradley Segal J, Nguyen EL, Barsh GR, Maskatia S, Mathew R (2020) COVID19 and kawasaki disease: novel virus and novel case. Hosp Pediatr. https://doi.org/10.1542/hpeds.2020-0123

32. Mathian A, Mahevas M, Rohmer J, Roumier M, Cohen-Aubart F, Amador-Borrero B, Barrelet A, Chauvet C, Chazal T, Delahousse M, Devaux M, Euvrard R, Fadlallah J, Florens N, Haroche J, Hie M, Juillard L, Lhote R, Maillet T, Richard-Colmant G, Palluy JB, Pha M, Perard L, Remy P, Riviere E, Sene D, Seve P, Morelot-Panzini C, Viallard JF, Virot JS, Benameur N, Zahr N, Yssel H, Godeau B, Amoura Z (2020) Clinical course of coronavirus disease 2019 (COVID-19) in a series of 17 patients with systemic lupus erythematosus under long-term treatment with hydroxychloroquine. Ann Rheum Dis. https://doi.org/10.1136/ annrheumdis-2020-217566

33. Mihai C, Dobrota R, Schroder M, Garaiman A, Jordan S, Becker MO, Maurer B, Distler O (2020) COVID-19 in a patient with systemic sclerosis treated with tocilizumab for SSc-ILD. Ann Rheum Dis 79:668-669. https://doi.org/10.1136/annrheumdi s-2020-217442

34. Monti S, Balduzzi S, Delvino P, Bellis E, Quadrelli VS, Montecucco C (2020) Clinical course of COVID-19 in a series of patients with chronic arthritis treated with immunosuppressive targeted therapies. Ann Rheum Dis 79:667-668. https://doi. org/10.1136/annrheumdis-2020-217424
35. Song J, Kang S, Choi SW, Seo KW, Lee S, So MW, Lim DH (2020) Coronavirus Disease 19 (COVID-19) complicated with pneumonia in a patient with rheumatoid arthritis receiving conventional disease-modifying antirheumatic drugs. Rheumatol Int. https://doi.org/10.1007/s00296-020-04584-7

36. Damiani G, Pacifico A, Bragazzi NL, Malagoli P (2020) Biologics increase the risk of SARS- CoV-2 infection and hospitalization, but not ICU admission and death: real-life data from a large cohort during RED-ZONE declaration. Dermatol Ther. https://doi.org/10.1111/dth.13475

37. Dousa KM, Malavade SS, Furin J, Gripshover B, Hatszegi M, Hojat L, Saade E, Salata RA (2020) SARS-CoV-2 infection in a patient on chronic hydroxychloroquine therapy: implications for prophylaxis. IDCases. https://doi.org/10.1016/j.idcr.2020. e00778

38. Duret PM, Sebbag E, Mallick A, Gravier S, Spielmann L, Messer L (2020) Recovery from COVID-19 in a patient with spondyloarthritis treated with TNF-alpha inhibitor etanercept. Ann Rheum Dis. https://doi.org/10.1136/annrheumdis-2020217362

39. Emmi G, Bettiol A, Mattioli I, Silvestri E, Di Scala G, Urban ML, Vaglio A, Prisco D (2020) SARS-CoV-2 infection among patients with systemic autoimmune diseases. Autoimmun Rev. https://doi.org/10.1016/j.autrev.2020.102575

40. Favalli EG, Ingegnoli F, Cimaz R, Caporali R (2020) What is the true incidence of COVID-19 in patients with rheumatic diseases? Ann Rheum Dis. https://doi.org/10.1136/annrheumdis-2020217615

41. Konig MF, Kim AH, Scheetz MH, Graef ER, Liew JW, Simard J, Machado PM, Gianfrancesco M, Yazdany J, Langguth D, Robinson PC, Alliance C-GR (2020) Baseline use of hydroxychloroquine in systemic lupus erythematosus does not preclude SARS-CoV-2 infection and severe COVID-19. Ann Rheum Dis. https://doi.org/10.1136/annrheumdis-2020-217690

42. Moutsopoulos HM (2020) Anti-inflammatory therapy may ameliorate the clinical picture of COVID-19. Ann Rheum Dis. https ://doi.org/10.1136/annrheumdis-2020-217562

43. Tomelleri A, Sartorelli S, Campochiaro C, Baldissera EM, Dagna L (2020) Impact of COVID-19 pandemic on patients with largevessel vasculitis in Italy: a monocentric survey. Ann Rheum Dis. https://doi.org/10.1136/annrheumdis-2020-217600

44. Garg S, Kim L, Whitaker M, O'Halloran A, Cummings C, Holstein R, Prill M, Chai SJ, Kirley PD, Alden NB, Kawasaki B, Yousey-Hindes K, Niccolai L, Anderson EJ, Openo KP, Weigel A, Monroe ML, Ryan P, Henderson J, Kim S, Como-Sabetti K, Lynfield R, Sosin D, Torres S, Muse A, Bennett NM, Billing L, Sutton M, West N, Schaffner W, Talbot HK, Aquino C, George A, Budd A, Brammer L, Langley G, Hall AJ, Fry A (2020) Hospitalization rates and characteristics of patients hospitalized with laboratory-confirmed coronavirus disease 2019 - COVID-NET, 14 States, March 1-30, 2020. MMWR Morb Mortal Wkly Rep 69:458-464. https://doi.org/10.15585/mmwr.mm6915e3

45. Gendelman O, Amital H, Bragazzi NL, Watad A, Chodick G (2020) Continuous hydroxychloroquine or colchicine therapy does not prevent infection with SARS-CoV-2: insights from a large healthcare database analysis. Autoimmun Rev. https://doi. org/10.1016/j.autrev.2020.102566

46. Sirotich E, Dillingham S, Grainger R, Hausmann JS, Committee C-GRAS (2020) Capturing patient-reported outcomes during the COVID-19 pandemic: development of the COVID-19 global rheumatology alliance patient experience survey. Arthritis Care Res (Hoboken). https://doi.org/10.1002/acr.24257

47. Xu B, Fan CY, Wang AL, Zou YL, Yu YH, He C, Xia WG, Zhang JX, Miao Q (2020) Suppressed T cell-mediated immunity in patients with COVID-19: a clinical retrospective study in Wuhan, China. J Infect. https://doi.org/10.1016/j.jinf.2020.04.012 
48. Lee PI, Hu YL, Chen PY, Huang YC, Hsueh PR (2020) Are children less susceptible to COVID-19? J Microbiol Immunol Infect. https://doi.org/10.1016/j.jmii.2020.02.011

49. Brodin P (2020) Why is COVID-19 so mild in children? Acta Paediatr. https://doi.org/10.1111/apa.15271

50. Liu Y, Yan LM, Wan L, Xiang TX, Le A, Liu JM, Peiris M, Poon LLM, Zhang W (2020) Viral dynamics in mild and severe cases of COVID-19. Lancet Infect Dis. https://doi.org/10.1016/S1473 $-3099(20) 30232-2$

51. Nickbakhsh S, Mair C, Matthews L, Reeve R, Johnson PCD, Thorburn F, von Wissmann B, Reynolds A, McMenamin J, Gunson RN, Murcia PR (2019) Virus-virus interactions impact the population dynamics of influenza and the common cold. Proc Natl Acad Sci USA. https://doi.org/10.1073/pnas.1911083116

52. Carsetti R, Quintarelli C, Quinti I, Piano Mortari E, Zumla A, Ippolito G, Locatelli F (2020) The immune system of children: the key to understanding SARS-CoV-2 susceptibility? The Lancet Child \& Adolescent Health. https://doi.org/10.1016/S2352 $-4642(20) 30135-8$

53. Chen J JQ, Xia X, Liu K, Yu Z, Tao W, Gang W, Han J-D J (2020) Individual variation of the SARS-CoV2 receptor ACE2 gene expression and regulation. Preprints:2020030191

54. Lu X, Zhang L, Du H, Zhang J, Li YY, Qu J, Zhang W, Wang Y, Bao S, Li Y, Wu C, Liu H, Liu D, Shao J, Peng X, Yang Y, Liu Z, Xiang Y, Zhang F, Silva RM, Pinkerton KE, Shen K, Xiao H, Xu S, Wong GWK, Chinese Pediatric Novel Coronavirus Study T (2020) SARS-CoV-2 infection in children. N Engl J Med 382:1663-1665. https://doi.org/10.1056/NEJMc2005073

55. Roberts L (2020) Pandemic brings mass vaccinations to a halt. Science 368:116-117. https://doi.org/10.1126/scien ce.368.6487.116

56. She J, Liu L, Liu W (2020) COVID-19 epidemic: disease characteristics in children. J Med Virol. https://doi.org/10.1002/ jmv. 25807

57. Chen H, Guo J, Wang C, Luo F, Yu X, Zhang W, Li J, Zhao D, Xu D, Gong Q, Liao J, Yang H, Hou W, Zhang Y (2020) Clinical characteristics and intrauterine vertical transmission potential of COVID-19 infection in nine pregnant women: a retrospective review of medical records. Lancet 395:809-815. https://doi. org/10.1016/S0140-6736(20)30360-3

58. Netea MG, Joosten LA, Latz E, Mills KH, Natoli G, Stunnenberg HG, O’Neill LA, Xavier RJ (2016) Trained immunity: a program of innate immune memory in health and disease. Science 352:1098. https://doi.org/10.1126/science.aaf1098

59. Miller A, Reandelar MJ, Fasciglione K, Roumenova V, Li Y, Otazu GH (2020) Correlation between universal BCG vaccination policy and reduced morbidity and mortality for COVID-19: an epidemiological study. medRxiv. https://doi. org/10.1101/2020.03.24.20042937

60. Moorlag S, Arts RJW, van Crevel R, Netea MG (2019) Non-specific effects of BCG vaccine on viral infections. Clin Microbiol Infect 25:1473-1478. https://doi.org/10.1016/j.cmi.2019.04.020

61. Arts RJW, Moorlag S, Novakovic B, Li Y, Wang SY, Oosting M, Kumar V, Xavier RJ, Wijmenga C, Joosten LAB, Reusken C, Benn CS, Aaby P, Koopmans MP, Stunnenberg HG, van Crevel R, Netea MG (2018) BCG vaccination protects against experimental viral infection in humans through the induction of cytokines associated with trained immunity. Cell Host Microbe 23(89-100):e105. https://doi.org/10.1016/j.chom.2017.12.010

62. Berg RE, Cordes CJ, Forman J (2002) Contribution of CD8+ $\mathrm{T}$ cells to innate immunity: IFN-gamma secretion induced by IL-12 and IL-18. Eur J Immunol 32:2807-2816. https://doi. org/10.1002/1521-4141(2002010)32:10<2807:AID-IMMU2 807>3.0.CO;2-0

63. Berg RE, Crossley E, Murray S, Forman J (2003) Memory $\mathrm{CD} 8+\mathrm{T}$ cells provide innate immune protection against
Listeria monocytogenes in the absence of cognate antigen. J Exp Med 198:1583-1593. https://doi.org/10.1084/jem.20031 051

64. Lertmemongkolchai G, Cai G, Hunter CA, Bancroft GJ (2001) Bystander activation of $\mathrm{CD} 8+\mathrm{T}$ cells contributes to the rapid production of IFN-gamma in response to bacterial pathogens. J Immunol 166:1097-1105. https://doi.org/10.4049/jimmu nol.166.2.1097

65. Mathurin KS, Martens GW, Kornfeld H, Welsh RM (2009) CD4 T-cell-mediated heterologous immunity between mycobacteria and poxviruses. J Virol 83:3528-3539. https://doi.org/10.1128/ JVI.02393-08

66. Kleinnijenhuis J, Quintin J, Preijers F, Joosten LA, Ifrim DC, Saeed S, Jacobs C, van Loenhout J, de Jong D, Stunnenberg HG, Xavier RJ, van der Meer JW, van Crevel R, Netea MG (2012) Bacille Calmette-Guerin induces NOD2-dependent nonspecific protection from reinfection via epigenetic reprogramming of monocytes. Proc Natl Acad Sci U S A 109:17537-17542. https ://doi.org/10.1073/pnas.1202870109

67. Franklin R, Young A, Neumann B, Fernandez R, Joannides A, Reyahi A, Modis Y (2020) Homologous protein domains in SARS-CoV-2 and measles, mumps and rubella viruses: preliminary evidence that MMR vaccine might provide protection against COVID-19. medRxiv. https://doi. org/10.1101/2020.04.10.20053207

68. Bianchi FP, Stefanizzi P, De Nitto S, Larocca AMV, Germinario C, Tafuri S (2020) Long-term immunogenicity of measles vaccine: an italian retrospective cohort study. J Infect Dis 221:721728. https://doi.org/10.1093/infdis/jiz508

69. Shanker V (2020) Measles immunization: worth considering containment strategy for SARS-CoV-2 global outbreak. Indian Pediatr 57:380

70. Atzeni F, Gerardi MC, Barilaro G, Masala IF, Benucci M, Sarzi-Puttini P (2018) Interstitial lung disease in systemic autoimmune rheumatic diseases: a comprehensive review. Expert Rev Clin Immunol 14:69-82. https://doi.org/10.1080/17446 66X.2018.1411190

71. Malattia C, Martini A (2013) Paediatric-onset systemic lupus erythematosus. Best Pract Res Clin Rheumatol 27:351-362. https ://doi.org/10.1016/j.berh.2013.07.007

72. Ravelli A, Davi S, Minoia F, Martini A, Cron RQ (2015) Macrophage activation syndrome. Hematol Oncol Clin North Am 29:927-941. https://doi.org/10.1016/j.hoc.2015.06.010

73. Cron RQ, Chatham WW (2020) The rheumatologist's role in COVID-19. J Rheumatol. https://doi.org/10.3899/jrheum.200334

74. Cron RQ, Davi S, Minoia F, Ravelli A (2015) Clinical features and correct diagnosis of macrophage activation syndrome. Expert Rev Clin Immunol 11:1043-1053. https://doi.org/10.1586/17446 66X.2015.1058159

75. Rodriguez-Morales AJ, Cardona-Ospina JA, Gutierrez-Ocampo E, Villamizar-Pena R, Holguin-Rivera Y, Escalera-Antezana JP, Alvarado-Arnez LE, Bonilla-Aldana DK, Franco-Paredes C, Henao-Martinez AF, Paniz-Mondolfi A, Lagos-Grisales GJ, Ramirez-Vallejo E, Suarez JA, Zambrano LI, Villamil-Gomez WE, Balbin-Ramon GJ, Rabaan AA, Harapan H, Dhama K, Nishiura H, Kataoka H, Ahmad T, Sah R (2020) Clinical, laboratory and imaging features of COVID-19: a systematic review and meta-analysis. Travel Med Infect Dis. https://doi.org/10.1016/j. tmaid.2020.101623

76. Zhan J, Deng R, Tang J, Zhang B, Tang Y, Wang JK, Li F, Anderson VM, McNutt MA, Gu J (2006) The spleen as a target in severe acute respiratory syndrome. FASEB J 20:2321-2328. https://doi.org/10.1096/fj.06-6324com

77. Henter JI, Horne A, Arico M, Egeler RM, Filipovich AH, Imashuku S, Ladisch S, McClain K, Webb D, Winiarski J, Janka G (2007) HLH-2004: diagnostic and therapeutic guidelines for 
hemophagocytic lymphohistiocytosis. Pediatr Blood Cancer 48:124-131. https://doi.org/10.1002/pbc.21039

78. Barton LM, Duval EJ, Stroberg E, Ghosh S, Mukhopadhyay S (2020) COVID-19 autopsies, Oklahoma, USA. Am J Clin Pathol. https://doi.org/10.1093/ajcp/aqaa062

79. Menter T, Haslbauer JD, Nienhold R, Savic S, Hopfer H, Deigendesch N, Frank S, Turek D, Willi N, Pargger H, Bassetti S, Leuppi JD, Cathomas G, Tolnay M, Mertz KD, Tzankov A (2020) Post-mortem examination of COVID19 patients reveals diffuse alveolar damage with severe capillary congestion and variegated findings of lungs and other organs suggesting vascular dysfunction. Histopathology. https://doi.org/10.1111/his.14134

80. Bouaziz JD, Duong T, Jachiet M, Velter C, Lestang P, Cassius C, Arsouze A, Domergue Than Trong E, Bagot M, Begon E, Sulimovic L, Rybojad M (2020) Vascular skin symptoms in COVID19: a french observational study. J Eur Acad Dermatol Venereol. https://doi.org/10.1111/jdv.16544

81. Sonmez HE, Karaaslan C, de Jesus AA, Batu ED, Anlar B, Sozeri B, Bilginer Y, Karaguzel D, Cagdas Ayvaz D, Tezcan I, Goldbach-Mansky R, Ozen S (2020) A clinical score to guide in decision making for monogenic type I IFNopathies. Pediatr Res 87:745-752. https://doi.org/10.1038/s41390-019-0614-2

82. Basatneh R, Vlahovic TC (2020) Addressing the question of dermatologic manifestations of SARS-CoV-2 infection in the lower extremities: a closer look at the available data and its implications. J Am Podiatr Med Assoc. https://doi.org/10.7547/20-074

83. Fernandez-Nieto D, Jimenez-Cauhe J, Suarez-Valle A, MorenoArrones OM, Saceda-Corralo D, Arana-Raja A, Ortega-Quijano D (2020) Characterization of acute acro-ischemic lesions in non-hospitalized patients: a case series of 132 patients during the COVID-19 outbreak. J Am Acad Dermatol. https://doi. org/10.1016/j.jaad.2020.04.093

84. Zhang Y, Cao W, Xiao M, Li YJ, Yang Y, Zhao J, Zhou X, Jiang W, Zhao YQ, Zhang SY, Li TS (2020) Clinical and coagulation characteristics of 7 patients with critical COVID-2019 pneumonia and acro-ischemia. Zhonghua Xue Ye Xue Za Zhi 41:E006. https://doi.org/10.3760/cma.j.issn.0253-2727.2020.0006

85. Batu ED, Karadag O, Taskiran EZ, Kalyoncu U, Aksentijevich I, Alikasifoglu M, Ozen S (2015) A case series of adenosine deaminase 2-deficient patients emphasizing treatment and genotypephenotype correlations. J Rheumatol 42:1532-1534. https://doi. org/10.3899/jrheum.150024

86. Ozen S, Batu ED, Taskiran EZ, Ozkara HA, Unal S, Guleray N, Erden A, Karadag O, Gumruk F, Cetin M, Sonmez HE, Bilginer Y, Ayvaz DC, Tezcan I (2020) A Monogenic disease with a variety of phenotypes: deficiency of adenosine deaminase 2 . J Rheumatol 47:117-125. https://doi.org/10.3899/jrheum.181384

87. Zhang Y, Xiao M, Zhang S, Xia P, Cao W, Jiang W, Chen H, Ding $X$, Zhao H, Zhang H, Wang C, Zhao J, Sun X, Tian R, Wu W, Wu D, Ma J, Chen Y, Zhang D, Xie J, Yan X, Zhou X, Liu Z, Wang J, Du B, Qin Y, Gao P, Qin X, Xu Y, Zhang W, Li T, Zhang F, Zhao Y, Li Y, Zhang S (2020) Coagulopathy and antiphospholipid antibodies in patients with Covid-19. N Engl J Med 382:e38. https://doi.org/10.1056/NEJMc2007575

88. Riphagen S, Gomez X, Gonzalez-Martinez C, Wilkinson N, Theocharis $\mathrm{P}$ (2020) Hyperinflammatory shock in children during COVID-19 pandemic. Lancet. https://doi.org/10.1016/S0140 $-6736(20) 31094-1$

89. Li Y, Zheng Q, Zou L, Wu J, Guo L, Teng L, Zheng R, Jung LKL, Lu M (2019) Kawasaki disease shock syndrome: clinical characteristics and possible use of IL-6, IL-10 and IFN-gamma as biomarkers for early recognition. Pediatr Rheumatol Online $\mathbf{J}$ 17:1. https://doi.org/10.1186/s12969-018-0303-4

90. Oxley TJ, Mocco J, Majidi S, Kellner CP, Shoirah H, Singh IP, De Leacy RA, Shigematsu T, Ladner TR, Yaeger KA, Skliut M, Weinberger J, Dangayach NS, Bederson JB, Tuhrim S, Fifi JT
(2020) Large-vessel stroke as a presenting feature of Covid-19 in the Young. N Engl J Med. https://doi.org/10.1056/NEJMc20097 87

91. Lachmann HJ (2017) Periodic fever syndromes. Best Pract Res Clin Rheumatol 31:596-609. https://doi.org/10.1016/j. berh.2017.12.001

92. Ozen S, Batu ED, Demir S (2017) Familial Mediterranean fever: recent developments in pathogenesis and new recommendations for management. Front Immunol 8:253. https://doi.org/10.3389/ fimmu.2017.00253

93. Cattan D (2005) MEFV mutation carriers and diseases other than familial Mediterranean fever: proved and non-proved associations; putative biological advantage. Curr Drug Targets Inflamm Allergy 4:105-112. https://doi.org/10.2174/1568010053622948

94. Chung LK, Park YH, Zheng Y, Brodsky IE, Hearing P, Kastner DL, Chae JJ, Bliska JB (2016) The yersinia virulence factor yopm hijacks host kinases to inhibit type III effector-triggered activation of the pyrin inflammasome. Cell Host Microbe 20:296-306. https://doi.org/10.1016/j.chom.2016.07.018

95. Chen IY, Moriyama M, Chang MF, Ichinohe T (2019) severe acute respiratory syndrome coronavirus viroporin $3 \mathrm{a}$ activates the NLRP3 inflammasome. Front Microbiol 10:50. https://doi. org/10.3389/fmicb.2019.00050

96. Shi CS, Nabar NR, Huang NN, Kehrl JH (2019) SARS-coronavirus open reading frame- $8 \mathrm{~b}$ triggers intracellular stress pathways and activates NLRP3 inflammasomes. Cell Death Discov 5:101. https://doi.org/10.1038/s41420-019-0181-7

97. Zhang T, Du H, Feng S, Wu R, Chen T, Jiang J, Peng Y, Ye C, Fang R (2019) NLRP3/ASC/Caspase-1 axis and serine protease activity are involved in neutrophil IL-1beta processing during Streptococcus pneumoniae infection. Biochem Biophys Res Commun 513:675-680. https://doi.org/10.1016/j. bbrc.2019.04.004

98. Walker UA, Hoffman HM, Williams R, Kuemmerle-Deschner J, Hawkins PN (2016) Brief report: severe inflammation following vaccination against Streptococcus pneumoniae in patients with cryopyrin-associated periodic syndromes. Arthritis Rheumatol 68:516-520. https://doi.org/10.1002/art.39482

99. Vastert SJ, van Wijk R, D'Urbano LE, de Vooght KM, de Jager W, Ravelli A, Magni-Manzoni S, Insalaco A, Cortis E, van Solinge WW, Prakken BJ, Wulffraat NM, de Benedetti F, Kuis W (2010) Mutations in the perforin gene can be linked to macrophage activation syndrome in patients with systemic onset juvenile idiopathic arthritis. Rheumatology (Oxford) 49:441-449. https://doi.org/10.1093/rheumatology/kep418

100. Canna SW, de Jesus AA, Gouni S, Brooks SR, Marrero B, Liu Y, DiMattia MA, Zaal KJ, Sanchez GA, Kim H, Chapelle D, Plass N, Huang Y, Villarino AV, Biancotto A, Fleisher TA, Duncan JA, O'Shea JJ, Benseler S, Grom A, Deng Z, Laxer RM, GoldbachMansky R (2014) An activating NLRC4 inflammasome mutation causes autoinflammation with recurrent macrophage activation syndrome. Nat Genet 46:1140-1146. https://doi.org/10.1038/ ng.3089

101. Sawalha AH, Zhao M, Coit P, Lu Q (2020) Epigenetic dysregulation of ACE2 and interferon-regulated genes might suggest increased COVID-19 susceptibility and severity in lupus patients. Clin Immunol 215:108410. https://doi.org/10.1016/j. clim.2020.108410

102. Ferro F, Elefante E, Baldini C, Bartoloni E, Puxeddu I, Talarico R, Mosca M, Bombardieri S (2020) COVID-19: the new challenge for rheumatologists. Clin Exp Rheumatol 38:175-180

103. Au K, Reed G, Curtis JR, Kremer JM, Greenberg JD, Strand V, Furst DE, Investigators C (2011) High disease activity is associated with an increased risk of infection in patients with rheumatoid arthritis. Ann Rheum Dis 70:785-791. https://doi. org/10.1136/ard.2010.128637 
104. Danza A, Ruiz-Irastorza G (2013) Infection risk in systemic lupus erythematosus patients: susceptibility factors and preventive strategies. Lupus 22:1286-1294. https://doi.org/10.1177/09612 03313493032

105. Sheahan TP, Sims AC, Graham RL, Menachery VD, Gralinski LE, Case JB, Leist SR, Pyrc K, Feng JY, Trantcheva I, Bannister R, Park Y, Babusis D, Clarke MO, Mackman RL, Spahn JE, Palmiotti CA, Siegel D, Ray AS, Cihlar T, Jordan R, Denison MR, Baric RS (2017) Broad-spectrum antiviral GS-5734 inhibits both epidemic and zoonotic coronaviruses. Sci Transl Med. https ://doi.org/10.1126/scitranslmed.aal3653

106. Grein J, Ohmagari N, Shin D, Diaz G, Asperges E, Castagna A, Feldt T, Green G, Green ML, Lescure FX, Nicastri E, Oda R, Yo K, Quiros-Roldan E, Studemeister A, Redinski J, Ahmed S, Bernett J, Chelliah D, Chen D, Chihara S, Cohen SH, Cunningham J, D'Arminio Monforte A, Ismail S, Kato H, Lapadula G, L'Her E, Maeno T, Majumder S, Massari M, Mora-Rillo M, Mutoh Y, Nguyen D, Verweij E, Zoufaly A, Osinusi AO, DeZure A, Zhao Y, Zhong L, Chokkalingam A, Elboudwarej E, Telep L, Timbs L, Henne I, Sellers S, Cao H, Tan SK, Winterbourne L, Desai P, Mera R, Gaggar A, Myers RP, Brainard DM, Childs R, Flanigan T (2020) Compassionate use of remdesivir for patients with severe Covid-19. N Engl J Med. https://doi.org/10.1056/ NEJMoa2007016

107. Wang Y, Zhang D, Du G, Du R, Zhao J, Jin Y, Fu S, Gao L, Cheng Z, Lu Q, Hu Y, Luo G, Wang K, Lu Y, Li H, Wang S, Ruan S, Yang C, Mei C, Wang Y, Ding D, Wu F, Tang X, Ye X, Ye Y, Liu B, Yang J, Yin W, Wang A, Fan G, Zhou F, Liu Z, Gu X, Xu J, Shang L, Zhang Y, Cao L, Guo T, Wan Y, Qin H, Jiang Y, Jaki T, Hayden FG, Horby PW, Cao B, Wang C (2020) Remdesivir in adults with severe COVID-19: a randomised, doubleblind, placebo-controlled, multicentre trial. Lancet. https://doi. org/10.1016/S0140-6736(20)31022-9

108. Yao TT, Qian JD, Zhu WY, Wang Y, Wang GQ (2020) A systematic review of lopinavir therapy for SARS coronavirus and MERS coronavirus-A possible reference for coronavirus disease-19 treatment option. J Med Virol. https://doi.org/10.1002/jmv.25729

109. Cao B, Wang Y, Wen D, Liu W, Wang J, Fan G, Ruan L, Song B, Cai Y, Wei M, Li X, Xia J, Chen N, Xiang J, Yu T, Bai T, Xie X, Zhang L, Li C, Yuan Y, Chen H, Li H, Huang H, Tu S, Gong F, Liu Y, Wei Y, Dong C, Zhou F, Gu X, Xu J, Liu Z, Zhang Y, Li H, Shang L, Wang K, Li K, Zhou X, Dong X, Qu Z, Lu S, Hu X, Ruan S, Luo S, Wu J, Peng L, Cheng F, Pan L, Zou J, Jia C, Wang J, Liu X, Wang S, Wu X, Ge Q, He J, Zhan H, Qiu F, Guo L, Huang C, Jaki T, Hayden FG, Horby PW, Zhang D, Wang C (2020) A trial of lopinavir-ritonavir in adults hospitalized with severe covid-19. N Engl J Med 382:1787-1799. https ://doi.org/10.1056/NEJMoa2001282

110. Little $P(2020)$ Non-steroidal anti-inflammatory drugs and covid19. BMJ 368:m1185. https://doi.org/10.1136/bmj.m1185

111. Fang L, Karakiulakis G, Roth M (2020) Are patients with hypertension and diabetes mellitus at increased risk for COVID-19 infection? Lancet Respir Med 8:e21. https://doi.org/10.1016/ S2213-2600(20)30116-8

112. Day M (2020) Covid-19: ibuprofen should not be used for managing symptoms, say doctors and scientists. BMJ 368:m1086. https://doi.org/10.1136/bmj.m1086

113. Giollo A, Adami G, Gatti D, Idolazzi L, Rossini M (2020) Coronavirus disease 19 (Covid-19) and non-steroidal anti-inflammatory drugs (NSAID). Ann Rheum Dis. https://doi.org/10.1136/ annrheumdis-2020-217598

114. Le Bourgeois M, Ferroni A, Leruez-Ville M, Varon E, Thumerelle C, Bremont F, Fayon MJ, Delacourt C, Ligier C, Watier L, Guillemot D, Children ANA-iD, Childhood Empyema Study G (2016) Nonsteroidal anti-inflammatory drug without antibiotics for acute viral infection increases the empyema risk in children: a matched case-control study. J Pediatr 175(4753):e43. https://doi.org/10.1016/j.jpeds.2016.05.025

115. Voiriot G, Philippot Q, Elabbadi A, Elbim C, Chalumeau M, Fartoukh M (2019) Risks related to the use of non-steroidal anti-inflammatory drugs in community-acquired pneumonia in adult and pediatric patients. J Clin Med. https://doi. org/10.3390/jcm8060786

116. Batu ED (2019) Glucocorticoid treatment in juvenile idiopathic arthritis. Rheumatol Int 39:13-27. https://doi.org/10.1007/ s00296-018-4168-0

117. Chan ED, Chan MM, Chan MM, Marik PE (2020) Use of glucocorticoids in the critical care setting: science and clinical evidence. Pharmacol Ther 206:107428. https://doi. org/10.1016/j.pharmthera.2019.107428

118. Chen RC, Tang XP, Tan SY, Liang BL, Wan ZY, Fang JQ, Zhong N (2006) Treatment of severe acute respiratory syndrome with glucosteroids: the Guangzhou experience. Chest 129:1441-1452. https://doi.org/10.1378/chest.129.6.1441

119. Ho JC, Ooi GC, Mok TY, Chan JW, Hung I, Lam B, Wong PC, Li PC, Ho PL, Lam WK, Ng CK, Ip MS, Lai KN, Chan-Yeung M, Tsang KW (2003) High-dose pulse versus nonpulse corticosteroid regimens in severe acute respiratory syndrome. Am J Respir Crit Care Med 168:1449-1456. https://doi.org/10.1164/ rccm.200306-766OC

120. Yam LY, Lau AC, Lai FY, Shung E, Chan J, Wong V, Hong Kong Hospital Authority SCG (2007) Corticosteroid treatment of severe acute respiratory syndrome in Hong Kong. J Infect 54:28-39. https://doi.org/10.1016/j.jinf.2006.01.005

121. Auyeung TW, Lee JS, Lai WK, Choi CH, Lee HK, Lee JS, Li PC, Lok KH, Ng YY, Wong WM, Yeung YM (2005) The use of corticosteroid as treatment in SARS was associated with adverse outcomes: a retrospective cohort study. J Infect 51:98-102. https://doi.org/10.1016/j.jinf.2004.09.008

122. Tsai MJ, Yang KY, Chan MC, Kao KC, Wang HC, Perng WC, Wu CL, Liang SJ, Fang WF, Tsai JR, Chang WA, Chien YC, Chen WC, Hu HC, Lin CY, Chao WC, Sheu CC, for Taiwan Severe Influenza Research Consortium I (2020) Impact of corticosteroid treatment on clinical outcomes of influenza-associated ARDS: a nationwide multicenter study. Ann Intensive Care 10:26. https://doi.org/10.1186/s13613-020-0642-4

123. Wu C, Chen X, Cai Y, Xia J, Zhou X, Xu S, Huang H, Zhang L, Zhou X, Du C, Zhang Y, Song J, Wang S, Chao Y, Yang Z, Xu J, Zhou X, Chen D, Xiong W, Xu L, Zhou F, Jiang J, Bai C, Zheng J, Song Y (2020) Risk factors associated with acute respiratory distress syndrome and death in patients with coronavirus disease 2019 pneumonia in Wuhan, China. JAMA Intern Med. https://doi.org/10.1001/jamainternmed.2020.0994

124. Wang Y, Jiang W, He Q, Wang C, Wang B, Zhou P, Dong N, Tong Q (2020) A retrospective cohort study of methylprednisolone therapy in severe patients with COVID-19 pneumonia. Signal Transduct Target Ther 5:57. https://doi.org/10.1038/ s41392-020-0158-2

125. Bertsias GK, Tektonidou M, Amoura Z, Aringer M, Bajema I, Berden JH, Boletis J, Cervera R, Dorner T, Doria A, Ferrario F, Floege J, Houssiau FA, Ioannidis JP, Isenberg DA, Kallenberg CG, Lightstone L, Marks SD, Martini A, Moroni G, Neumann I, Praga M, Schneider M, Starra A, Tesar V, Vasconcelos C, van Vollenhoven RF, Zakharova H, Haubitz M, Gordon C, Jayne D, Boumpas DT, European League Against R, European Renal Association-European D, Transplant A (2012) Joint European league against rheumatism and European Renal association-European Dialysis and Transplant Association (EULAR/ERA-EDTA) recommendations for the management of adult and paediatric lupus nephritis. Ann Rheum Dis 71:1771-1782. https://doi.org/10.1136/annrheumdis-2012201940 
126. Scuccimarri R, Sutton E, Fitzcharles MA (2020) Hydroxychloroquine: a potential ethical dilemma for rheumatologists during the COVID-19 pandemic. J Rheumatol. https://doi.org/10.3899/ jrheum. 200369

127. Shah S, Das S, Jain A, Misra DP, Negi VS (2020) A systematic review of the prophylactic role of chloroquine and hydroxychloroquine in coronavirus disease-19 (COVID-19). Int J Rheum Dis. https://doi.org/10.1111/1756-185X.13842

128. Gautret P, Lagier JC, Parola P, Hoang VT, Meddeb L, Mailhe M, Doudier B, Courjon J, Giordanengo V, Vieira VE, Dupont HT, Honore S, Colson P, Chabriere E, La Scola B, Rolain JM, Brouqui P, Raoult D (2020) Hydroxychloroquine and azithromycin as a treatment of COVID-19: results of an open-label nonrandomized clinical trial. Int J Antimicrob Agents. https://doi. org/10.1016/j.ijantimicag.2020.105949

129. Marmor MF, Kellner U, Lai TY, Melles RB, Mieler WF, American Academy of O (2016) Recommendations on screening for chloroquine and hydroxychloroquine retinopathy (2016 revision). Ophthalmology 123:1386-1394. https://doi.org/10.1016/j.ophth a.2016.01.058

130. O'Laughlin JP, Mehta PH, Wong BC (2016) Life threatening severe QTc prolongation in patient with systemic lupus erythematosus due to hydroxychloroquine. Case Rep Cardiol 2016:4626279. https://doi.org/10.1155/2016/4626279

131. Mason JW (2017) Antimicrobials and QT prolongation. J Antimicrob Chemother 72:1272-1274. https://doi.org/10.1093/jac/ dkw591

132. Saleh M, Gabriels J, Chang D, Kim BS, Mansoor A, Mahmood E, Makker P, Ismail H, Goldner B, Willner J, Beldner S, Mitra R, John R, Chinitz J, Skipitaris N, Mountantonakis S, Epstein LM (2020) The effect of chloroquine, hydroxychloroquine and azithromycin on the corrected QT interval in patients with SARS-CoV-2 infection. Circ Arrhythm Electrophysiol. https:// doi.org/10.1161/CIRCEP.120.008662

133. Miserocchi E, Giuffre C, Cornalba M, Pontikaki I, Cimaz R (2020) JAK inhibitors in refractory juvenile idiopathic arthritis-associated uveitis. Clin Rheumatol 39:847-851. https://doi. org/10.1007/s10067-019-04875-w

134. Sanchez GAM, Reinhardt A, Ramsey S, Wittkowski H, Hashkes PJ, Berkun Y, Schalm S, Murias S, Dare JA, Brown D, Stone DL, Gao L, Klausmeier T, Foell D, de Jesus AA, Chapelle DC, Kim H, Dill S, Colbert RA, Failla L, Kost B, O’Brien M, Reynolds JC, Folio LR, Calvo KR, Paul SM, Weir N, Brofferio A, Soldatos A, Biancotto A, Cowen EW, Digiovanna JJ, Gadina M, Lipton AJ, Hadigan C, Holland SM, Fontana J, Alawad AS, Brown RJ, Rother KI, Heller T, Brooks KM, Kumar P, Brooks SR, Waldman M, Singh HK, Nickeleit V, Silk M, Prakash A, Janes JM, Ozen S, Wakim PG, Brogan PA, Macias WL, Goldbach-Mansky R (2018) JAK1/2 inhibition with baricitinib in the treatment of autoinflammatory interferonopathies. J Clin Invest 128:3041-3052. https:// doi.org/10.1172/JCI98814

135. Favalli EG, Biggioggero M, Maioli G, Caporali R (2020) Baricitinib for COVID-19: a suitable treatment? Lancet Infect Dis. https://doi.org/10.1016/S1473-3099(20)30262-0

136. Richardson P, Griffin I, Tucker C, Smith D, Oechsle O, Phelan A, Stebbing J (2020) Baricitinib as potential treatment for 2019$\mathrm{nCoV}$ acute respiratory disease. Lancet 395:e30-e31. https://doi. org/10.1016/S0140-6736(20)30304-4

137. Fensterl V, Sen GC (2009) Interferons and viral infections. BioFactors 35:14-20. https://doi.org/10.1002/biof.6

138. Smolen JS, Genovese MC, Takeuchi T, Hyslop DL, Macias WL, Rooney T, Chen L, Dickson CL, Riddle Camp J, Cardillo TE, Ishii T, Winthrop KL (2019) Safety profile of baricitinib in patients with active rheumatoid arthritis with over 2 years median time in treatment. J Rheumatol 46:7-18. https://doi.org/10.3899/ jrheum. 171361
139. Ruan Q, Yang K, Wang W, Jiang L, Song J (2020) Clinical predictors of mortality due to COVID-19 based on an analysis of data of 150 patients from Wuhan China. Intensive Care Med. https://doi.org/10.1007/s00134-020-05991-x

140. Alattar R, Ibrahim TBH, Shaar SH, Abdalla S, Shukri K, Daghfal JN, Khatib MY, Aboukamar M, Abukhattab M, Alsoub HA, Almaslamani MA, Omrani AS (2020) Tocilizumab for the treatment of severe coronavirus disease 2019. J Med Virol. https:// doi.org/10.1002/jmv.25964

141. Alzghari SK, Acuna VS (2020) Supportive treatment with tocilizumab for COVID-19: a systematic review. J Clin Virol 127:104380. https://doi.org/10.1016/j.jcv.2020.104380

142. Toniati P, Piva S, Cattalini M, Garrafa E, Regola F, Castelli F, Franceschini F, Foca E, Andreoli L, Latronico N, Brescia International R, Training HUB (2020) Tocilizumab for the treatment of severe COVID-19 pneumonia with hyperinflammatory syndrome and acute respiratory failure: a single center study of 100 patients in Brescia, Italy. Autoimmun Rev 10:2568. https://doi. org/10.1016/j.autrev.2020.102568

143. Klopfenstein T, Zayet S, Lohse A, Balblanc JC, Badie J, Royer PY, Toko L, Mezher C, Kadiane-Oussou NJ, Bossert M, Bozgan AM, Charpentier A, Roux MF, Contreras R, Mazurier I, Dussert P, Gendrin V, Conrozier T (2020) Tocilizumab therapy reduced intensive care unit admissions and/or mortality in COVID-19 patients. Med Mal Infect. https://doi.org/10.1016/j.medma 1.2020.05.001

144. Sciascia S, Apra F, Baffa A, Baldovino S, Boaro D, Boero R, Bonora S, Calcagno A, Cecchi I, Cinnirella G, Converso M, Cozzi M, Crosasso P, De Iaco F, Di Perri G, Eandi M, Fenoglio R, Giusti M, Imperiale D, Imperiale G, Livigni S, Manno E, Massara C, Milone V, Natale G, Navarra M, Oddone V, Osella S, Piccioni P, Radin M, Roccatello D, Rossi D (2020) Pilot prospective open, single-arm multicentre study on off-label use of tocilizumab in patients with severe COVID-19. Clin Exp Rheumatol

145. Balasubramanian S, Nagendran TM, Ramachandran B, Ramanan AV (2020) Hyper-inflammatory syndrome in a child with COVID-19 treated successfully with intravenous immunoglobulin and tocilizumab. Indian Pediatr

146. Odievre MH, de Marcellus C, Ducou Le Pointe H, Allali S, Romain AS, Youn J, Taytard J, Nathan N, Corvol H (2020) Dramatic improvement after Tocilizumab of a severe COVID-19 in a child with sickle cell disease and acute chest syndrome. Am J Hematol. https://doi.org/10.1002/ajh.25855

147. Cavalli G, De Luca G, Campochiaro C, Della-Torre E, Ripa M, Canetti D, Oltolini C, Castiglioni B, Tassan Din C, Boffini N, Tomelleri A, Farina N, Ruggeri A, Rovere-Querini P, Di Lucca G, Martinenghi S, Scotti R, Tresoldi M, Ciceri F, Landoni G, Zangrillo A, Scarpellini P, Dagna L (2020) Interleukin-1 blockade with high-dose anakinra in patients with COVID-19, acute respiratory distress syndrome, and hyperinflammation: a retrospective cohort study. Lancet Rheumatol. https://doi.org/10.1016/ S2665-9913(20)30127-2

148. Lythgoe MP, Middleton P (2020) Ongoing clinical trials for the management of the COVID-19 pandemic. Trends Pharmacol Sci. https://doi.org/10.1016/j.tips.2020.03.006

149. Costi S, Caporali R, Cimaz R (2020) Dealing with COVID-19 in a pediatric rheumatology unit in Italy. Paediatr Drugs. https:// doi.org/10.1007/s40272-020-00395-2

150. Gasparyan AY, Misra DP, Yessirkepov M, Zimba O (2020) Perspectives of immune therapy in coronavirus disease 2019. J Korean Med Sci 35:e176. https://doi.org/10.3346/jkms.2020.35. e176

151. Ahn JY, Sohn Y, Lee SH, Cho Y, Hyun JH, Baek YJ, Jeong SJ, Kim JH, Ku NS, Yeom JS, Roh J, Ahn MY, Chin BS, Kim YS, Lee H, Yong D, Kim HO, Kim S, Choi JY (2020) Use of convalescent plasma therapy in two COVID-19 patients with 
acute respiratory distress syndrome in Korea. J Korean Med Sci 35:e149. https://doi.org/10.3346/jkms.2020.35.e149

152. Duan K, Liu B, Li C, Zhang H, Yu T, Qu J, Zhou M, Chen L, Meng S, Hu Y, Peng C, Yuan M, Huang J, Wang Z, Yu J, Gao X, Wang D, Yu X, Li L, Zhang J, Wu X, Li B, Xu Y, Chen W, Peng Y, Hu Y, Lin L, Liu X, Huang S, Zhou Z, Zhang L, Wang Y, Zhang Z, Deng K, Xia Z, Gong Q, Zhang W, Zheng X, Liu Y, Yang H, Zhou D, Yu D, Hou J, Shi Z, Chen S, Chen Z, Zhang X, Yang X (2020) Effectiveness of convalescent plasma therapy in severe COVID-19 patients. Proc Natl Acad Sci USA 117:9490-9496. https://doi.org/10.1073/pnas.2004168117

153. Shen C, Wang Z, Zhao F, Yang Y, Li J, Yuan J, Wang F, Li D, Yang M, Xing L, Wei J, Xiao H, Yang Y, Qu J, Qing L, Chen L, Xu Z, Peng L, Li Y, Zheng H, Chen F, Huang K, Jiang Y, Liu D, Zhang Z, Liu Y, Liu L (2020) Treatment of 5 critically ill patients with COVID-19 with convalescent plasma. JAMA. https://doi. org/10.1001/jama.2020.4783

154. Ye M, Fu D, Ren Y, Wang F, Wang D, Zhang F, Xia X, Lv $\mathrm{T}$ (2020) Treatment with convalescent plasma for COVID-19 patients in Wuhan. China. J Med Virol. https://doi.org/10.1002/ jmv. 25882

155. Zhang B, Liu S, Tan T, Huang W, Dong Y, Chen L, Chen Q, Zhang L, Zhong Q, Zhang X, Zou Y, Zhang S (2020) Treatment with convalescent plasma for critically ill patients with
SARS-CoV-2 infection. Chest. https://doi.org/10.1016/j.chest 2020.03.039

156. Filocamo G, Minoia F, Carbogno S, Costi S, Romano M, Cimaz R, Pediatric Rheumatology Group of the Milan A (2020) Absence of severe complications from SARS-CoV-2 infection in children with rheumatic diseases treated with biologic drugs. J Rheumatol. https://doi.org/10.3899/jrheum.200483

157. Sarzi-Puttini P, Marotto D, Antivalle M, Salaffi F, Atzeni F, Maconi G, Monteleone G, Rizzardini G, Antinori S, Galli M, Ardizzone S (2020) How to handle patients with autoimmune rheumatic and inflammatory bowel diseases in the COVID19 era: An expert opinion. Autoimmun Rev. https://doi. org/10.1016/j.autrev.2020.102574

158. Gupta L, Misra DP, Agarwal V, Balan S, Agarwal V (2020) Management of rheumatic diseases in the time of covid-19 pandemic: perspectives of rheumatology practitioners from India. Ann Rheum Dis. https://doi.org/10.1136/annrheumdis-2020-217509

Publisher's Note Springer Nature remains neutral with regard to jurisdictional claims in published maps and institutional affiliations. 